\title{
Polska wobec wyzwań polityki imigracyjnej w kontekście portugalskich doświadczeń
}

Punktem wyjścia prowadzonego w tym artykule wywodu jest teza o istniejących między Polską a Portugalią podobieństwach z zakresu zagadnień migracyjnych. W pierwszym rzędzie, celem wykazania owych podobieństw, autorka prześledziła historię Portugalii z perspektywy migracyjnej od czasów wielkich odkryć geograficznych. Jednocześnie wybrane portugalskie doświadczenia odniesiono do sytuacji Polski w omawianym zakresie. Następnie przybliżono wdrożone w Portugalii określone rozwiązania o charakterze politycznym, które wpisują się w ramy - wysuwanych przez Rafała Matyję, Annę Siewierską-Chmaj i Konrada Pędziwiatra - poszczególnych postulatów zasadniczych wytycznych polskiej doktryny imigracyjnej. A wspomnianymi postulatami są: po pierwsze, udzielanie ochrony uchodźcom; po drugie, działanie na rzecz szeroko pojmowanej repatriacji; po trzecie, otwarcie na migrantów z Europy, a także z innych zbliżonych do niej pod względem kulturowym obszarów i dostrzeżenie w nich potencjalnych współobywateli oraz po czwarte, przedsiębranie działań mających na celu sprowadzenie do Polski wysoko wykwalifikowanych obcokrajowców.

Słowa kluczowe: Polska, Portugalia, imigrant, integracja imigrantów

\section{Poland and a challenge of immigration policy in the context of Portuguese experience}

The thesis that there is a resemblance between Poland and Portugal in the field of migration issues is serving as a starting point for this article. First of all, the author looks at the history of Portugal since the Age of Exploration from a migration perspective. At the same time, the chosen events of Portuguese history refer to the situation of Poland within the scope of this article. Then, the author describes specific political solutions implemented in Portugal, which are compatible with a suggestion for the fundamental guidelines on the Polish immigration doctrine put forward by Rafał Matyja, Anna Siewierska-Chmaj, and Konrad Pędziwiatr. Those

${ }^{1}$ Kontakt: magdalena.gasior@op.pl 
guideposts are: firstly; protection for refugees, secondly; working for broadly understood repatriation, thirdly; being open to migrants from Europe, as well as from other culturally similar areas and identifying them as potential fellow citizens, fourthly; undertaking a task aimed at bringing highly qualified foreigners to Poland.

Keywords: Poland, Portugal, immigrant, immigrant integration

W perspektywie europejskiej Polska wydaje się krajem bardzo odległym od Portugalii nie tylko pod względem geograficznym, historycznym, ale i ogólnie rzecz ujmując - kulturowym. Specyfika każdego z tych krajów zdaje się nie przystawać do siebie również w obszarze zagadnień migracyjnych. Wystarczy choćby wspomnieć o rozległych portugalskich doświadczeniach kolonialnych i ich wpływie na kształtowanie współczesnych strumieni migracyjnych, zarówno tych kierujących się do Portugalii, jak i z niej wypływających. Niemniej jednak w tej materii, pomimo bezsprzecznych różnic, można wskazać występujące między Polską i Portugalią podobieństwa, spośród których nie sposób nie odnotować charakteryzującej oba państwa długiej historii emigracyjnej i dość krótkiej imigracyjnej. Stanowi to interesujący kontekst porównawczy, mając zwłaszcza na uwadze utrzymywanie się Portugalii, niezmiennie od 2007 r., na wysokim, drugim miejscu w Indeksie Polityki Integracji Imigrantów $(\mathrm{MIPEX})^{2}$. Tym samym - w dobie nasilających się migracji międzynarodowych i przybierającej na znaczeniu problematyce funkcjonowania imigrantów w państwach przyjmujących - Portugalię, jak się zdaje, można w tym zakresie uznać za dobry przykład dla Polski.

W pierwszej kolejności (celem ukazania owego zakładanego potencjału porównawczego), w odniesieniu do polskich doświadczeń, została zarysowana historia migracyjna Portugalii. Następnie - w oparciu o rozważania Macieja Duszczyka, dotyczące rozumienia pojęć „doktryna” i „polityka” w kontekście zagadnień

2 Tylko w pierwszej edycji przywołanego indeksu z 2004 r. (noszącego wówczas nazwę European Civic Citizenship and Inclusion Index), w którym wzięto pod uwagę 15 państw członkowskich UE, Portugalia zajęła czwartą pozycję. W kolejnych trzech edycjach MIPEX (z 2007, 2011 i 2015 r.) Portugalia uplasowała się na drugim miejscu. Przy tym w r. 2007 badaniami objęto już 25 państw UE (po rozszerzeniu z 2004 r.), a także Norwegię, Szwajcarię i Kanadę. W r. 2011 w porównaniu z rokiem 2007 w indeksie uwzględniono dodatkowe 2 państwa, które stały się nowymi członkami UE oraz Stany Zjednoczone Ameryki. Zaś w r. 2015 dołączyły jeszcze: Australia, Islandia, Turcja, Korea Południowa, Japonia i Nowa Zelandia oraz Chorwacja, która w międzyczasie uzyskała status państwa członkowskiego UE. Zob. European Civic Citizenship and Inclusion Index 2004, s. 29, http://www. mipex.eu/sites/default/files/downloads/files/europeanciviccitizenship-and-inclusionindex_2005. pdf, pdf s. 42, [data dostępu: 25.08.2016]; Migrant Integration Policy Index 2007, s. 3, http://www. mipex.eu/sites/default/files/downloads/migrant_integration_policy_index_mipex_ii-2007.pdf, pdf s. 17, [data dostępu: 25.08.2016]; Migrant Integration Policy Index III 2011, s. 11, http://www.mipex. eu/sites/default/files/downloads/migrant_integration_policy_index_mipexiii_2011.pdf, pdf s. 15, [data dostępu: 25.08.2016] oraz Migrant Integration Policy Index 2015, http://www.mipex.eu/portugal, [data dostępu: 25.08.2016]. 
migracyjnych - została przywołana wysunięta przez Rafała Matyję, Annę Siewierską-Chmaj i Konrada Pędziwiatra propozycja czterech głównych założeń polskiej doktryny imigracyjnej. Dalej, proponowane założenia, w które wpisują się jednocześnie wyzwania polskiej polityki imigracyjnej, zostały odniesione do portugalskich rozwiązań o charakterze politycznym w omawianym zakresie.

Przechodząc do nakreślenia portugalskiej historii migracyjnej, należy zacząć od wpływu, jaki wywarła prowadzona przez to państwo ekspansja zamorska ${ }^{3}$. Odwołując się do przemyśleń brytyjskiego historyka Davida Higgsa, można wyszczególnić trzy etapy tej ekspansji, które zarazem obrazują sposób kształtowania się obejmujących Portugalię strumieni migracyjnych. Pierwszy etap był związany z tworzeniem imperium handlowego poza Europą. Drugi - to „imperium surowców”, a trzeci - „imperium emigrantów”.

Uważane za „narodziny oficjalnej polityki ekspansji zamorskiej” zdobycie w 1415 r. położonej na marokańskim wybrzeżu Ceuty, zainicjowało budowę portugalskiej potęgi handlowej. Następnie Portugalczycy zajęli wyspy należące do archipelagu Madery ${ }^{6}$, przystępując do ich zasiedlania ${ }^{7}$. Potem rozpoczęli kolonizację Azorów, wznieśli fort Arguin w Mauretanii, dotarli kolejno do Archipelagu Zielonego Przylądka oraz Wysp Świętego Tomasza i Książęcej, a także utworzyli faktorię królewską w Beninie. Zaś w następstwie opłynięcia przez Bartolomeu Diasa Przylądka Dobrej Nadziei, w 1498 r. wyprawa z Vasco da Gamą na czele dobiła do Indii ${ }^{8}$. I to właśnie „[p]rzyczółki w Indiach, a później Makao okazały się najcenniejszymi zdobyczami. Budowano jednak dalsze bazy w Afryce Wschodniej, na Morzu Południowochińskim, w Japonii, archipelagu Indonezji”". Do Portugalii

${ }^{3}$ Według portugalskiego historyka José Hermano Saraivy w przypadku Portugalii „(...) przedsięwzięcia morskie były (...) głównie dziełem państwa, podczas gdy w innych krajach były zaledwie odizolowanymi i pozbawionymi ciągłości poczynaniami kupców lub awanturników”. J.H. Saraiva (2000), Krótka historia Portugalii, przeł. E. Łukaszyk, Kraków: Towarzystwo Autorów i Wydawców Prac Naukowych UNIVERSITAS, s. 136.

${ }^{4}$ D. Higgs (1990), Portuguese Migration Before 1880, w: D. Higgs (red.) Portuguese Migration in Global Perspective, Toronto: The Multicultural History Society of Ontario, s. 8-9. Zob. też A. Walaszek (2013), Dwie europejskie peryferie: porównanie migracji portugalskich i polskich od XVI wieku do Wielkiej Wojny, „Studia Migracyjne - Przegląd Polonijny”, z. 2 (148), s. 16-34 i M. Gąsior (2014), Integracja imigrantów w społeczeństwie osiedlenia na przykładzie Portugalii, praca magisterska napisana w Instytucie Amerykanistyki i Studiów Polonijnych Uniwersytetu Jagiellońskiego, s. 43-59. W obydwu powyższych pracach, zarysowując historię migracyjną Portugalii, posłużono się ukutym przez D. Higgsa podziałem na trzy imperia.

${ }^{5}$ J.H. Saraiva, op. cit., s. 125.

${ }^{6}$ Zob. A.H. de Oliveira Marques (1987), Historia Portugalii, t. I, przeł. J.Z. Klave, Warszawa: Państwowe Wydawnictwo Naukowe, s. 133-134.

7 Zob. D. Higgs, op. cit., s. 9.

${ }^{8}$ Zob. J. Kieniewicz (1983), Historia Półwyspu Iberyjskiego, Część I od czasów prehistorycznych do nowożytności, Warszawa: Wydawnictwo Uniwersytetu Warszawskiego, s. 137-140 i A. Walaszek, op. cit., s. 16-17.

\footnotetext{
${ }_{9}$ A. Walaszek, op. cit., s. 17.
} 
napływało złoto, porcelana i różnego rodzaju przyprawy ${ }^{10}$. Ponadto nie sposób tutaj nie wspomnieć o portugalskim udziale w handlu niewolnikami. W wyniku owego procederu - który zaczął się rozrastać w połowie XV w. - za pośrednictwem portów w Algarve i Lizbonie rokrocznie, w charakterze niewolniczej siły roboczej, przywożono do Europy średnio 700-800 osób. Część z nich była wykorzystywana do pracy na plantacjach trzciny cukrowej na Maderze bądź prac domowych w Lizbonie $^{11}$. W 1500 r. płynący do Indii Pedro Álvares Cabral ostatecznie dotarł do Brazylii, skąd zaczęto czerpać cenne drewno ${ }^{12}$. Jednak pobudką do zainicjowania procesu kolonizacji tego obszaru stały się dla Portugalczyków dopiero poczynania podejmowane w tym zakresie przez Francuzów. Zaczęli oni mianowicie dyskretnie włączać się do lukratywnej działalności handlowej i próbowali zagarnąć brazylijskie obszary $^{13}$. Z Brazylii także eksportowano cukier, do produkcji którego - podobnie jak miało to miejsce na Maderze, tylko na o wiele większą skalę - wykorzystywano niewolników. Właściciele młynów cukrowych utrzymywali bezpośrednie relacje z wybrzeżem gwinejskim, aby pozyskiwać stamtąd Afrykańczyków do pracy na plantacjach ${ }^{14}$. To „zapotrzebowanie” na niewolniczą siłę roboczą doprowadziło do wytworzenia się między Brazylią a Afryką szczególnego rodzaju „więzi”"15. Szacuje się, że u schyłku XVIII w. pod portugalską kontrolą znajdowało się ok. 38\% transatlantyckiego handlu niewolnikami ${ }^{16}$. Oprócz kierunków bardzo odległych, Portugalczycy migrowali również w granicach Europy. Jak zaznacza portugalski historyk António Henrique de Oliveira Marques „całe kolonie” parających się handlem rezydentów osiedliły się w Kastylii, Flandrii, Francji i Anglii oraz na terytorium dzisiejszych Włoch. Jednocześnie z wymienionych powyżej obszarów - a także z Niemiec, dokąd udawało się niewielu Portugalczyków - zajmujący się handlem obcokrajowcy przybywali do Portugalii (zatrzymując się przede wszystkim w Lizbonie, ale również w Porto i w Algarve) $)^{17}$.

Przyjrzyjmy się sytuacji Pierwszej Rzeczypospolitej w tym samym czasie. Na przestrzeni XV i XVIII w. (posiłkując się określeniem Janusza Tazbira) było to

${ }^{10}$ Ibid.

11 A.H. de Oliveira Marques, Historia..., t. I, s. 142.

12 „Podstawą rozkwitu było drewno brazyliowe (pau-brasil). W latach 1506-1507 wysyłano do Portugalii średnio około 20 tys. kwintali drewna rocznie, które sprzedawano z wielkim zyskiem w całej Europie”. A.H. de Oliveira Marques, Historia..., t. I, s. 240.

${ }_{13}$ A. Walaszek, op. cit., s. 18; A.H. de Oliveira Marques, Historia .., t. I, s. 241 i J.H. Saraiva, op. cit., s. 165.

${ }^{14}$ J.H. Saraiva, op. cit., s. 166.

15 A.H. de Oliveira Marques, Historia..., t. I, s. 258.

${ }^{16}$ C. Nogueira da Silva, K. Grinberg (2011), Soil Free from Slaves: Slave Law in Late Eighteenthand Early Nineteenth-Century Portugal, „Slavery \& Abolition”, Vol. 32, No. 3, September, https:// extranet.uj.edu.pl/eds/pdfviewer/,DanaInfo=eds.a.ebscohost.com + pdfviewer?vid=2\&sid=f88acd4af410-412d-86cb-813d2712977a\%40sessionmgr4006, pdf s. 2, [data dostępu: 21.06.2018].

17 A.H. de Oliveira Marques, Historia..., t. I, s. 152. 
„wieloetniczne państwo polsko-litewskie” ${ }^{18}$. Należy bowiem odnotować, za przywołanym powyżej polskim historykiem, że - wraz z włączaniem poszczególnych grup etnicznych czy narodowych w granice jednego bytu politycznego na drodze unii czy inkorporacji - ów „konglomerat różnych narodów (...) był wynikiem masowych migracji ludności, charakterystycznych dla całego kontynentu, począwszy od średniowiecza. Oprócz masowej kolonizacji niemieckiej, w całej niemal Europie osiadała ludność włoska, francuska czy holenderska (...)"19. Natomiast „(...) w odróżnieniu od zachodniej części kontynentu, w Polsce pojawiły się pochodzące z Azji grupy etniczno-wyznaniowe, które - jak Ormianie, Karaimi czy Tatarzy - zapuściły tu swoje korzenie na stałe"20. A co do ostatniej z wyszczególnionych grup, jak podkreśla Bogusław R. Zagórski, „[j]est to w gruncie rzeczy jedyny w Europie przykład społeczności muzułmańskiej, trwale istniejącej w kraju, który nigdy nie stanowił części świata islamu”21. Polska zatem, pomimo braku terytoriów zamorskich, nie była pozbawiona styczności z ludnością pozaeuropejską. Natomiast w XVII w. mieszkańcy ziem należących do Pierwszej Rzeczypospolitej zaczęli coraz liczniej je opuszczać, początkowo z przyczyn religijnych, a następnie również zarobkowych ${ }^{22}$. Mając na uwadze powyższe, zasadnym zdaje się uznanie, że Polska i Portugalia omawianego okresu nie kryją w sobie, poszukiwanego w tym artykule, wystarczającego potencjału porównawczego. Będąc, pomimo dzielącej oba kraje odległości, częścią jednego kontynentu, przynajmniej do pewnego stopnia obejmowały je te same trendy migracyjne. Trudno jednak byłoby nie zgodzić się z oceną, że ówczesna Polska i ówczesna Portugalia w przeważającym zakresie funkcjonowały w nieprzystających do siebie kontekstach.

Na marginesie można zauważyć, że siłą okoliczności w 1580 r. Portugalia weszła w unię personalną z Hiszpanią. Wówczas portugalski tron objął hiszpański władca Filip II $^{23}$. Z czasem (za panowania Filipa III i Filipa IV) portugalska zależność od Hiszpanii się wzmagała. Zaistniała sytuacja okazała się niekorzystna dla Portugalii, zarówno na arenie międzynarodowej, jak i wewnętrznej. Dotychczasowi

${ }_{18}$ J. Tazbir (2009), Rzeczpospolita wielu narodów, w: J. Kłoczowski (red.) Rzeczpospolita wielokulturowa - dobrodziejstwo czy obciązenie?, Warszawa: Collegium Civitas Press: Polski Komitet do spraw UNESCO, s. 61.

19 Ibid.

${ }^{20}$ Ibid.

${ }^{21}$ B.R. Zagórski (2009), Orientalizm lub orientalność polskiej wspólnoty etnicznej i politycznej $w$ aspekcie europejskim, w: J. Kłoczowski (red.) Rzeczpospolita wielokulturowa - dobrodziejstwo czy obciążenie?, Warszawa: Collegium Civitas Press: Polski Komitet do spraw UNESCO, s. 39.

${ }^{22}$ J. Tazbir, op. cit., s. 61-62.

${ }^{23}$ A.H. de Oliveira Marques za wydarzenie otwierające drogę do unii iberyjskiej uznaje śmierć w bitwie portugalskiego króla Sebastiana z dynastii Avis. Jako że nie miał on potomka, w 1978 r. rządy w Portugalii przejął Henryk, już wówczas schorowany, stryjeczny dziad Sebastiana. Po jego śmierci nieprzezwyciężonym kandydatem do portugalskiego tronu okazał się właśnie hiszpański władca Filip II. Zob. A.H. de Oliveira Marques, Historia..., t. I, s. 287 i 289-292. 
portugalscy sprzymierzeńcy: Anglia ${ }^{24}$ i Holandia, korzystając z napiętych stosunków z Hiszpanią, przystąpili do sukcesywnego przejmowania, kontrolowanego od ponad wieku przez Portugalię, handlu ze Wschodem. Tymczasem w granicach Portugalii mierzono się z prowadzoną przez Hiszpanów polityką o charakterze asymilacyjnym oraz wysokimi podatkami. W końcu, po licznych buntach, w 1640 roku udało się Portugalczykom przy pomocy Francji wzniecić, zakończone sukcesem, powstanie i powołać na tron księcia Jana de Bragança. Tym samym po sześćdziesięciu latach Portugalia proklamowała niepodległość, która została uznana przez Hiszpanię, po długotrwałych walkach, mocą traktatu pokojowego z $1668 \mathrm{roku}^{25}$. Jak można zatem zauważyć, Portugalii nieobcy był konflikt z państwem ościennym, którego stawką była m.in. suwerenność oraz tożsamość etniczna. I chociaż zestawienie w tym kontekście Portugalii i Polski wraz z jej relacjami z państwami sąsiadującymi byłoby zapewne zbyt dużym uogólnieniem, to jednak wzmianka o tym aspekcie portugalskiej historii zdaje się pomocna w ukazaniu pełniejszego obrazu dziejów Portugalii w omawianym okresie.

Wyszczególniony przez D. Higgsa jako drugi, etap „imperium surowców” rozpoczął się ok. r. 1600. W tej fazie fundamentalną rolę odegrała Brazylia. Jak już wspomniano, najpierw eksportowano stamtąd drewno, potem coraz większe ilości cukru, a następnie złoto i diamenty. Przed powyższą cezurą liczba zasiedlających Brazylię Portugalczyków nie była znaczna, nie przewyższała nawet liczby portugalskich osadników na Maderze. Sytuacja ta jednak zaczęła ulegać zmianie. Po odzyskaniu przez Portugalczyków niezależności i wyparciu z Brazylii Holendrów, obszar ten stał się miejscem docelowym portugalskiego strumienia migracyjnego. Zasilali go m.in. pracownicy rolni, jak również urzędnicy, którzy napływali do Brazylii aż do czasu zrzucenia przez nią portugalskiego zwierzchnictwa w r. $1822^{26}$. Zaś na przełomie XVIII i XIX w., chociaż nie na masową skalę, do Portugalii przybywały osoby pochodzenia hiszpańskiego, brytyjskiego, niemieckiego i francuskiego, a także migranci z Brazylii. Dla przykładu, w poczet pierwszych z wymienionych wchodzili m.in. Galisyjczycy, którzy w głównej mierze wpisywali się w zjawisko migracji czasowych. Wielu z nich kierowało się na północ Portugalii, gdzie zatrudniali się w rolnictwie, wykonując określone prace sezonowe. Inni

${ }^{24}$ Warto tutaj odnotować szczególny charakter angielsko-portugalskich relacji. Wystarczy wspomnieć, że pierwszą w swojej historii międzypaństwową umowę handlową Portugalia podpisała w 1353 r. właśnie z Anglią. Co więcej, 20 lat później oba państwa zawarły przymierze przeciwko Kastylii. Z kolei w 1386 r. (w czasie wojny Kastylii z Portugalią) owo przymierze między Anglią i Portugalią zostało potwierdzone mocą formalnej umowy - traktatu windsorskiego. A.B. Cardoso (2003), Portugal e a Inglaterra nos tempos modernos, „Revista da faculdade de Letras. HISTÓRIA”, Porto, III Série, Vol. 4, https://repositorio-aberto.up.pt/bitstream/10216/7966/2/2349.pdf, pdf s. 1, [data dostępu: 21.06.2018].

${ }^{25}$ J.Z. Klave (1985), Historia literatury portugalskiej. Zarys, Wrocław: Zakład Narodowy imienia Ossolińskich Wydawnictwo, s. 130.

${ }^{26}$ D. Higgs, op. cit., s. 11. 
udawali się do większych ośrodków miejskich, zwłaszcza Lizbony, gdzie zajmowali się m.in. dostarczaniem wody, zanim zaczęto ją doprowadzać przy użyciu wodocią$\mathrm{gu}^{27}$. Natomiast gros przybywających do Portugalii Brytyjczyków migrowało całymi rodzinami, aby osiąść w północnej części kraju i rozwinąć działalność związaną z produkcją wina Porto ${ }^{28}$.

Jednak sukcesywnie, niejako wbrew zyskom płynącym z terytoriów zamorskich, sytuacja ekonomiczna Portugalii ulegała pogorszeniu. Nie udało jej się bowiem efektywnie spożytkować wpływów z handlu przyprawami, ani zysków z obrotu drewnem i cukrem, ani przychodów uzyskiwanych dzięki wydobyciu złota i diamentów ${ }^{29}$. Nadto „[p]ocząwszy od XVIII w. (i prawdę mówiąc, aż do XX w.) stale wzrastało podporządkowanie gospodarki portugalskiej interesom Anglii” ${ }^{30}$. Co więcej, zawarte w 1810 r. między Portugalią a Wielką Brytanią porozumienie handlowe sprawiło, że portugalskie terytoria zamorskie stały się „de facto przedłużenie[m] posiadłości brytyjskich”31. Dodatkową okolicznością sprzyjającą zacieśnianiu relacji między tymi dwoma państwami było wystąpienie w 1793 r. Portugalii przeciwko rewolucyjnej Francji. Posunięcie to postawiło Portugalię przed koniecznością odpierania, przy pomocy Wielkiej Brytanii, w latach 1807-1810 trzech inwazji wojsk napoleońskich ${ }^{32}$. Zgodnie z oceną portugalskiego historyka José Hermano Saraivy, wojna ta przewyższała zaciętością inne, toczone do tego czasu przez Portugalię i okazała się dla tego kraju katastrofalna pod wieloma względami. Nastąpiła zapaść

27 J.F. Alves, Imigração de galegos no Norte de Portugal (1500-1900). Algumas notas, http://ler. letras.up.pt/uploads/ficheiros/artigo11211.pdf, pdf s. 9, [data dostępu: 21.06.2018].

${ }^{28}$ E. Dionísio (2009), Políticas locais e acção colectiva dos imigrantes da Europa de leste, no concelho de Lisboa, Lisboa: Alto-Comissariado para a Imigração e Diálogo Intercultural (ACIDI, I.P.), s. 54-55, http://www.oi.acidi.gov.pt/docs/Colec_Teses/tese_27.pdf, pdf. s. 56-57, [data dostępu: 10.05.2013].

${ }^{29}$ Wraz z napływem niemałych kwot $\mathrm{z}$ handlu przyprawami, na początku XVI w. wzmogła się w Portugalii skłonność do pomnażania utrzymywanej przez państwo społeczności dworskiej, co następowało kosztem ludności produktywnej. Dwór królewski, zyskując na świetności, stał się zarazem bardziej liczny, a podstawowym kryterium społecznej wartości poszczególnych reprezentantów szlachty było praktykowanie życia w przepychu. Jednocześnie przedstawiciele wielkich arystokratycznych rodów zaciągali długi na rzecz utrzymywania własnych małych dworów. Zaś wzrost konsumpcji dóbr wiązał się ze zmniejszeniem dochodu narodowego. Natomiast jednym z głównych czynników portugalskiej niemocy, jeżeli chodzi o efektywne wykorzystanie pieniędzy ze zbytu drewna, cukru, złota i diamentów, wydaje się pogłębiające się w XVII w. opóźnienie tego kraju w porównaniu do innych, prężnie się rozwijających europejskich państw, przede wszystkim Anglii, Francji i Holandii. J.H. Saraiva, op. cit., s. 170-171 i 245-253.

30 A.H. de Oliveira Marques (1987), Historia Portugalii, t. II, przeł. W. Chabasiński, Warszawa: Państwowe Wydawnictwo Naukowe, s. 41. Za cezurę inicjującą okres dominacji gospodarczej, ale i politycznej, Anglii (a następnie Wielkiej Brytanii) nad Portugalią można uznać r. 1703, kiedy to oba te państwa zawarły umowę handlową (tzw. Traktat Methuena), postanowienia której były szczególnie korzystne dla Anglii właśnie. Zob. T. Wituch (2000), Historia Portugalii w XX wieku, Warszawa: Wyższa Szkoła Humanistyczna w Pułtusku, s. 1-18. Por. J.H. Saraiva, op. cit., s. 236-237.

31 T. Wituch, op. cit., s. 18.

${ }^{32}$ Zob. A.H. de Oliveira Marques, Historia..., t. II, s. 48-50. 
rolnictwa, przemysłu i handlu. Znaczne obszary, szczególnie w północnej Portugalii, zostały obrócone $\mathrm{w}$ ruinę ${ }^{33}$. Wcześniej natomiast, w następstwie trzęsienia ziemi z 1755 r., oprócz destrukcji ogromnej części zabudowy Lizbony, zniszczeniu uległy znaczne połacie południa kraju ${ }^{34}$. Nie wspominając o stratach w ludziach. Zaś kilkanaście lat później w Portugalii wybuchła wojna domowa. Na przestrzeni lat 1828-1834 ścierali się tam ze sobą, walcząc o formę sprawowania rządów w państwie, przedstawiciele konserwatystów i liberałów. Równocześnie w gospodarce rolnej zachodziły przekształcenia, wskutek których pogarszało się położenie mieszkańców wsi niemających gruntów na własnośćc ${ }^{35}$.

Trudno nie zauważyć, że wskazane powyżej uwarunkowania nie wpłynęły pozytywnie na kondycję życiową mieszkańców Portugalii, stwarzając „dogodną” sytuację dla „(...) exodus[u] ludzi młodych"36. I w taki oto sposób - ponownie odwołując się do rozważań D. Higgsa - Portugalia z „imperium surowców” przeobraziła się w „imperium emigrantów”, stanowiące finalny etap ekspansji zamorskiej tego państwa. Od połowy XIX w. bowiem „(...) już niekoniecznie do kolonii, ludzie wyjeżdżali z konieczności, by gromadzić i przekazywać pozostałym w Portugalii rodzinom zarobione pieniądze" ${ }^{37}$. Począwszy od lat 70. XIX w. rokrocznie emigrowało z Portugalii 13 tys. osób. W latach 1886-1890 liczba ta podwyższyła się do 21 tys., a w 1895 r. - do 42 tys. Najwięcej opuszczających Portugalię odnotowano w r. 1912, kiedy to wyjechało 89 tys. ówczesnych mieszkańców tego kraju ${ }^{38}$. Celem ich podróży - oprócz Brazylii, która w dalszym ciągu dla portugalskich migrantów pozostawała głównym państwem przyjmującym - była Wenezuela, Afryka Południowa, kraje europejskie z Francją na czele i Stany Zjednoczone Ameryki oraz Kanada ${ }^{39}$.

Wspomniany najwyższy w owym czasie stopień nasilenia emigracji z Portugalii przypadł już po proklamacji republiki, co nastąpiło w 1910 r. Obalenie monarchii nie przyczyniło się do poprawy złej kondycji ekonomicznej państwa. „Krok ten natomiast do reszty zdestabilizował sytuację polityczną. Niekompetencja nowej elity rządzącej dorównywała tylko jej demagogii" ${ }^{40}$. Tak duchowni, jak i świeccy katoliccy byli przez władze szykanowani ${ }^{41}$. Ponadto Portugalia odczuła negatywne

${ }^{33}$ Ibid., s. 50-51 i J.H. Saraiva, op. cit., s. 280.

${ }^{34}$ A.H. de Oliveira Marques, Historia..., t. II, s. 43. Por. N. Davies (2001), Europa: rozprawa historyka z historia, przeł. E. Tabakowska, Kraków: Wydawnictwo ZNAK, s. 685.

${ }^{35}$ Zob. J.H. Saraiva, op. cit., s. 295-298 i 325.

${ }^{36}$ A. Walaszek, op. cit., s. 22.

${ }^{37}$ Ibid., s. 16.

${ }^{38}$ Ibid., s. 27. Według przeprowadzonego z końcem 1911 r. spisu ludności, Portugalię kontynentalną wraz z archipelagami Madery i Azorów zamieszkiwało wówczas 5960056 osób. A.H. de Oliveira Marques, Historia..., t. II, s. 246.

${ }^{39}$ D. Higgs, op. cit., s. 12.

40 T. Wituch, op. cit., s. 37.

${ }^{41}$ Zob. ibid., s. 39-43 i 60-61. 
skutki przystąpienia do I wojny światowej. Poniesione na ten cel koszty pociągnęły za sobą reglamentacje żywności, energii elektrycznej i papieru. Portugalczycy musieli się również zmierzyć ze znaczącym wzrostem cen. W ciągu półtora roku od momentu włączenia się do wojny cena chleba poszła w górę o $130 \%^{42}$.

$\mathrm{Z}$ czasem portugalska waluta coraz bardziej traciła na wartości. Strajki, za pomocą których zrzeszający się w anarchizujących związkach zawodowych robotnicy domagali się podwyższenia płac, stały się niemal codziennością. W wydarzenia te poniekąd wpisane były brutalne starcia $\mathrm{z}$ siłami rządowymi ${ }^{43}$. Zmniejszony w okresie wojennym ruch migracyjny ponownie przybrał na sile. W 1920 r. Portugalię opuściło 65 tys. osób ${ }^{44}$. Głównym krajem przyjmującym w dalszym ciągu była dla nich Brazylia. Rokrocznie, do wybuchu wielkiego kryzysu gospodarczego, docierało tam 23 tys. Portugalczyków ${ }^{45}$.

Przewrót z 1926 r. zapoczątkował, trwający do 1933 r., okres wojskowej dyktatury w Portugalii ${ }^{46}$. „(...) jeden problem wyrastał ponad inne: utrzymanie porządku publicznego. Każda polityczna różnica zdań była traktowana jako atak na ten porządek i każdy kontakt z ludźmi, którzy w poprzednich latach sprawowali władzę w państwie, był podejrzany. Ustanowiono cenzurę publikacji sprawowaną przez komisje wojskowych" ${ }^{47}$. Represje przybrały na sile w r. 1927, gdy podjęta przez uprzednio rządzących próba odzyskania władzy zakończyła się fiaskiem. Wówczas też wzrosła liczba emigrantów. Jednocześnie zwiększeniu ulegały nakłady finansowe na wojsko, co pogłębiało deficyt budżetowy. W r. 1926/27, w przeliczeniu na brytyjską walutę, przewyższał on 3 mln funtów. W takiej sytuacji w $1928 \mathrm{r}$. ministrem finansów został prof. ekonomii z uniwersytetu w Coimbrze - António de Oliveira Salazar. Uzyskawszy prawo zawetowania każdej rządowej decyzji, stojącej w sprzeczności z prowadzoną przez niego polityką budżetową, przejął pełnię kontroli nad wydatkami wszystkich resortów ${ }^{48}$.

Nowego ministra finansów zaczęto niebawem uznawać za „(...) jedyną myślącą głowę w ekipie rządzącej dyktatury (...)"49. W krótkim czasie, bo już w r. budżetowym 1928/29, udało mu się bowiem wypracować (w przeliczeniu na funty brytyjskie) kilkunastomilionową nadwyżkę. Ustabilizował on również kurs portugalskiej waluty $^{50}$. Co więcej, kreowana przez A. Salazara polityka finansowa uznawana jest za powód, dla którego Portugalii nie objął (bądź objął w niewielkim stopniu) wielki

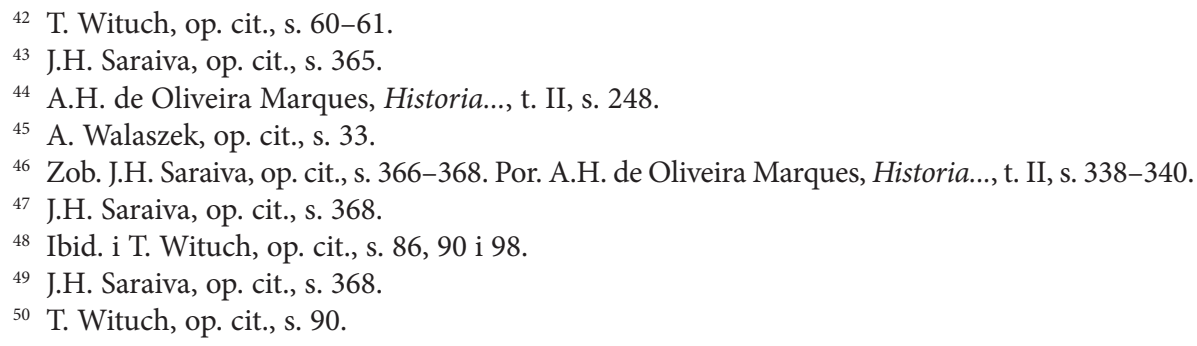


kryzys gospodarczy lat 1929-1933 ${ }^{51}$. Nie wdając się w rozważania z zakresu ekonomii, warto dodać, że ów kryzys, jak się wydaje, dał przyszłemu autokratycznemu przywódcy Portugalii - zgodnie z konstatacją portugalskiego uczonego José Luísa Cardoso - „(...) sposobność stworzenia jego momentum, co Salazar umiał wykorzystać jako pretekst i narzędzie politycznego triumfu"52.

W r. 1933, już z A. Salazarem, stojącym na czele portugalskiego rządu ${ }^{53}$, zaczęła obowiązywać ustawa zasadnicza, na mocy której przystąpiono do transformacji ustrojowej Portugalii. W ten sposób została formalnie zainicjowana budowa ${ }^{54}$, istniejącego do 1974 r., Nowego Państwa (Estado Novo) ${ }^{55}$ o faszystowskim charakterze. „Znacznie zredukowano prawa obywatelskie. W zamian za stabilność polityczną, porządek i powolny, ale stopniowy wzrost gospodarczy ograniczono swobody, zwłaszcza zrzeszania się i słowa" ${ }^{\text {". }}$. Ponadto prawo jednostki do opuszczenia kraju zostało podporządkowane (oczywiście definiowanemu przez władzę) dobru ogółu ${ }^{57}$. Z tego względu zjawisko emigracji włączono w zakres przedmiotowy polityki interwencjonistycznej państwa ${ }^{58}$. Przy czym należy uściślić, że jeszcze wcześniej, bo zapisem dekretu z mocą ustawy z 1929 r., wprowadzono zakaz wyjazdu z Portugalii osób między 14. a 45. rokiem życia, które nie legitymowały się ukończeniem szkoły podstawowej. Biorąc zaś pod uwagę wysoki stopień analfabetyzmu ówczesnego portugalskiego społeczeństwa, postanowienie to $\mathrm{w}$ teorii obejmowało większość Portugalczyków. Wracając do Nowego Państwa, trzeba zauważyć, że po tymczasowym całkowitym zakazie emigracji, w 1947 r. został utworzony specjalny urząd (Junta da Emigração) do sprawowania nadzoru nad emigracją właśnie. Do zadań tego urzędu, podlegającego jednocześnie ministrowi spraw zagranicznych i ministrowi spraw wewnętrznych, należało m.in. wdrażanie systemu kwotowego. Systemu, nieodłącznym elementem którego było ustalanie zważywszy na specyfikę poszczególnych regionów - maksymalnej aprobowanej

51 J.L. Cardoso (2012), Ecos da Grande Depressão em Portugal: relatos, diagnósticos e soluções, „Análise Social”, 203, XLVII (2. $\left.{ }^{\circ}\right), 2012$, https://extranet.uj.edu.pl/ehost/pdfviewer/,DanaInfo=web. ebscohost.com + pdfviewer?vid=4\&sid=eee2b546-dd00-4e1b-b0cb-78bd660e0850\%40sessionmgr111\&hid=125, pdf s. 7, [data dostępu: 12.05.2013].

${ }^{52}$ Ibid., pdf s. 30.

${ }^{53}$ Jednocześnie dalej pełnił on funkcję ministra finansów.

${ }^{54}$ Zob. J.H. Saraiva, op. cit., s. 368-371.

${ }_{55}$ Zob. M. Gąsior, op. cit., s. 63-71.

56 T. Wituch, op. cit., s. 100.

57 M.I. Baganha (2003), From Closed to Open Doors: Portuguese Emigration under the Corporatist Regime, „e-JPH”, Vol. 1, number 1, Summer, https://www.brown.edu/Departments/Portuguese_Brazilian_Studies/ejph/html/issue1/pdf/baganha.pdf, pdf s. 2, [data dostępu: 15.08.2017].

${ }^{58}$ Zgodnie z ust. 4 art. 31 konstytucji z 1933 r. w gestii portugalskiego państwa leżało sprawowanie kontroli nad emigracją. Zob. Constituição Política da República Portuguesa, 22 de Fevereiro de 1933, Diário do Govêrno, I Série - Número 43, https://dre.pt/application/dir/pdf1sdip/1933/02/04301/02270236.pdf, [data dostępu: 15.08.2017]. 
liczby emigrantów. Postanowieniem dekretu z mocą ustawy z r. 1962 liczba ta w skali roku nie miała przekroczyć 30 tys. (Jednak w praktyce system ten nie okazał się szczelny. W latach 1933-1974, czyli do momentu upadku Estado Novo, ok. $32 \%$ wszystkich opuszczających Portugalię dokonało tego potajemnie ${ }^{59}$.) U podstaw tych kształtujących emigrację działań leżały trzy odrębne, chociaż wzajemnie powiązane, cele. Pierwszym z nich było utrzymywanie odpowiedniej liczby pracowników odpowiadających na zapotrzebowanie krajowej gospodarki (aby to osiągnąć przeciwdziałano m.in. wyjazdom z Portugalii osób zatrudnionych). Drugim - zaspokojenie potrzeb portugalskich kolonii. A trzecim - czerpanie zysków z pieniędzy przesyłanych do ojczyzny przez emigrantów ${ }^{60}$.

Dla porządku należy dodać, że w latach 30 . XX w. średnia liczba osób opuszczających Portugalię w ciągu roku nie przekraczała 11 tys., a w kolejnej dekadzie 9 tys. $^{61}$. Nie wynikało to jednak z efektywności podejmowanych przez państwo działań administracyjnych, lecz było spowodowane pozostawaniem w kraju coraz to większej liczby potencjalnych emigrantów. U źródeł takiego stanu rzeczy leżało ożywienie portugalskiej gospodarki, przypływ kapitału i rozwijanie programu robót publicznych, dzięki czemu stwarzano dodatkowe miejsca pracy. Pod koniec 1935 r. stopień bezrobocia w Portugalii obniżył się do $1 \%{ }^{62}$.

Sytuacja w Portugalii zaczęła ulegać zmianie po II wojnie światowej. Wówczas to, odwołując się do stanowiska J. H. Saraivy, dały o sobie znać konsekwencje zaledwie częściowego przezwyciężenia utrzymującego się od wieków zapóźnienia obszarów wiejskich względem miast. „Istnienie dwóch, bardzo różniących się poziomów płac na wsi i w fabryce pociągało w wieku XX te same skutki, co w wieku XIX: intensywny ruch emigracyjny, stymulowany przez bliskość rynków pracy na kontynencie europejskim, gdzie poziom płac był o wiele wyższy" ${ }^{\prime 3}$. Ponadto

${ }^{59}$ M.I. Baganha, From Closed to..., pdf s. 3 i 5-6.

${ }^{60}$ S. Royo (2005), Portugal's Migration Experience: Redefined Boundaries and Uneasy Transformations, „Mediterranean Quarterly”, Vol. 16, Issue 4, https://extranet.uj.edu.pl/ehost/pdfviewer/,Da naInfo=web.b.ebscohost.com +pdfviewer?vid=4\&sid=a4d3b0f9-745f-44a8-8be0-871386938a6d $\% 40$ sessionmgr115\&hid=117, pdf s. 3, [data dostępu: 20.05.2013].

${ }^{61}$ M.I. Baganha, From Closed to..., pdf s. 3.

62 T. Wituch, op. cit., s. 109.

${ }^{63}$ J.H. Saraiva, op. cit., s. 373. Tutaj należy zauważyć, że po r. 1960, wbrew wcześniejszej tendencji, większość (75\%) wyjeżdżających z Portugalii pozostawało w Europie, udając się przede wszystkim do Francji i Niemiec Zachodnich. Jak bowiem wiadomo, państwa te - obok m.in. Holandii, Austrii i Belgii - potrzebowały wówczas rąk do pracy. Poszukiwane były osoby o niskich kwalifikacjach, a nawet bez kwalifikacji, które nie pozostałyby w kraju przyjmującym na stałe. Kryteria te zaś, przynajmniej w pewnej mierze, wpisywały się w założenia polityki emigracyjnej Nowego Państwa. Efektem owej zbieżności interesów było zawarcie przez Portugalię umów bilateralnych z Francją, Niemcami Zachodnimi i Holandią. Z perspektywy państwa A. Salazara owe porozumienia - oczywiście w powiązaniu z prawem krajowym - spełniały dwa podstawowe cele. Po pierwsze, zwiększały stopień kontroli ruchów emigracyjnych. Po drugie, pozwalały maksymalizować powroty, dzięki czemu więcej zarobionych za granicą pieniędzy wydawano w Portugalii. Należy przy tym pamiętać, że, jak już 
należy wspomnieć o negatywnym wpływie kosztownych wojen toczonych przez Portugalię z jej afrykańskimi koloniami oraz polityki Nowego Państwa. Dość zauważyć, że z czasem represyjność reżimu A. Salazara, którego w 1968 r. zastąpił Marcelo Caetano, przybierała na sile. Biorąc pod uwagę powyższe, nie dziwi natężenie emigracji z Portugalii, jakie nastąpiło w latach 60. i w pierwszej połowie lat 70. $\mathrm{XX}$ wieku ${ }^{64}$. Blisko 3/4, sięgającej niemal $2 \mathrm{mln}$, liczby Portugalczyków, którzy opuścili kraj w latach 1933-1974, wyemigrowało po roku $1960^{65}$.

Przysługujące każdej jednostce prawo do emigracji (oraz powrotu) zostało Portugalczykom zagwarantowane expressis verbis w obowiązującej do dzisiaj a uchwalonej dwa lata po wyznaczającej koniec Nowego Państwa rewolucji goździków - ustawie zasadniczej z roku $1976^{66}$. Jednak paradoksalnie, niejako wraz $\mathrm{z}$ wpisaniem prawa do opuszczenia kraju w katalog konstytucyjnych gwarancji, liczba wyjeżdżających zaczęła sukcesywnie maleć. W latach 1965-1974 z Portugalii w skali roku emigrowało średnio 122 tys. osób. Natomiast w latach 1975-1979 liczba opuszczających ojczyznę Portugalczyków zmniejszyła się z 52 tys. do 29 tys. ${ }^{67}$. Ponadto po 1974 r. do Portugalii wróciło kilkaset tysięcy jej obywateli, co było związane zarówno z procesem dekolonizacyjnym, jak i portugalską transformacją ustrojową. Chodzi tutaj o tzw. retornados - Portugalczyków powracających do kraju

wspomniano, zgodnie z dekretem z mocą ustawy z 1962 r. z Portugalii w skali roku nie mogło wyemigrować więcej niż 30 tys. ludzi. Ponadto zakazano opuszczania kraju przez osoby o określonych zawodach. Co więcej, w przypadku zaistnienia konfliktu między zapisami wspomnianych umów dwustronnych a przedsiębranymi w Portugalii środkami nadzoru nad emigracją, większą wagę przywiązywano do tych ostatnich. M.I. Baganha, From Closed to..., pdf s. 2-3, 6 oraz S. McLoughlin, R. Münz (2011), Temporary and Circular Migration: Opportunities and Challenges, European Policy Centre, Working Paper No. 35, http://www.epc.eu/documents/uploads/pub_1237_temporary_and_ circular_migration_wp35.pdf, pdf s. 21, [data dostępu: 15.07.2017].

${ }^{64}$ S. Royo, op. cit., pdf, s. 4 i 10.

${ }^{65}$ M.I. Baganha, From Closed to..., pdf, s. 6. Warto jednak zaznaczyć, że w 1960 r. Portugalia znajdowała się wśród państw założycielskich Europejskiego Stowarzyszenia Wolnego Handlu (EFTA), a w 1962 r. przystąpiła do Układu Ogólnego w sprawie Ceł i Handlu (GATT). „Bycie członkiem EFTA zaważyło na portugalskiej gospodarce. Uniemożliwiało ono przyjmowanie protekcjonistycznej polityki i wykluczało strategie gospodarcze oparte na substytucji importu, wymuszając w ten sposób otwarcie portugalskiej gospodarki i zapewnienie podstaw dla zorientowanej na eksport strategii uprzemysłowienia. Od 1960 do 1973 r. portugalski eksport do krajów EFTA wzrastał średnio o 16\% rocznie, co było jednym z czynników, które wpłynęły na szybki wzrost gospodarczy (ok. 7\%) we wspomnianym okresie, dając Portugalii sposobność rozwoju ponad dwie dekady przed przystąpieniem do EWG”. S. Royo, op. cit., pdf s. 22. Niemniej okoliczności te, jak już zostało zauważone, nie zapobiegły masowej emigracji Portugalczyków w tym czasie.

66 Zob. Konstytucja Republiki Portugalskiej z dnia 2 kwietnia 1976 r. (z późniejszymi zmianami, ostatnie wprowadzone ustawa konstytucyjna nr 1 z 20 września 1997 r.), art. 44 ust. 2, http://libr.sejm. gov.pl/tek01/txt/konst/portugalia.html, [data dostępu: 22.07.2017].

${ }^{67}$ M.I. Baganha, From Closed to..., pdf s. 6. Jako że, w związku z kryzysem naftowym z 1973 r., europejskie państwa zaczęły wycofywać się z przyjętej wobec gastarbeiterów strategii otwartych drzwi, emigracja z Portugalii nie tylko ulegała zmniejszeniu, ale i na powrót zaczął się zwiększać odsetek Portugalczyków wyruszających w podróż transoceaniczną. S. Royo, op. cit., pdf s. 5-6. 
z terenów byłych kolonii portugalskich ${ }^{68}$. Jak się okazało, była to zaledwie zapowiedź doniosłej, chociaż nietrwałej, przemiany w obszarze zjawisk migracyjnych. Tradycyjnie generująca emigrantów Portugalia w relatywnie krótkim czasie przeobraziła się bowiem w kraj imigracji ${ }^{69}$. Zaś u podstaw tej przemiany bez wątpienia znajdowała się znaczna poprawa sytuacji ekonomicznej Portugalii, która w 1986 r. wstąpiła do Europejskiej Wspólnoty Gospodarczej. Warto również wskazać, że w latach 80. i 90. XX w. Portugalię - obok Austrii, Holandii i Luksemburga - cechował najniższy poziom bezrobocia wśród państw członkowskich obecnej UE. Dodatkowymi czynnikami przyciągającymi imigrantów do Portugalii były jej uwarunkowania geograficzne, klimatyczne i kulturowe ${ }^{70}$.

Według szacunków, jeszcze w połowie lat 80 . XX w. od 3,5 mln do $4 \mathrm{mln}$ portugalskich obywateli - co stanowiło ponad 1/3 ludności mieszkającej w Portugalii - przebywało za granicą. Jednocześnie jednak Portugalia zaczęła doświadczać przybierającej na sile imigracji, co stało się szczególnie zauważalne od końca lat 80. XX w. W 1975 r. zezwoleniem na pobyt w Portugalii legitymizowało się 31 tys. obcokrajowców, stanowiąc $0,3 \%$ portugalskiej populacji. Analogicznie w 1989 r. - 101011 (1\%), w 1999 r. - 191143 (2\%), a w 2003 r. - $433650(4,23 \%)^{71}$. Pozytywny bilans migracyjny Portugalia uzyskała w pierwszej połowie lat 90 . XX w. Aczkolwiek liczba napływających do tego kraju osób w skali roku zaczęła przewyższać liczbę emigrujących już w latach 1975-1982. Było to związane ze strumieniami, jak wspomniano powyżej, powracających do ojczyzny portugalskich obywateli oraz udających się do Portugalii cudzoziemców pochodzących z jej byłych kolonii (zwłaszcza z Wysp Zielonego Przylądka, Angoli, Mozambiku i Gwinei Bissau $)^{72}$. Natomiast pośród przyczyn negatywnego bilansu migracyjnego

${ }^{68}$ Zob. S. Royo, op. cit., pdf, s. 2, i E. Dionísio, op. cit., pdf s. 58 oraz M.I. Baganha, Política de imigração: A regulação dos fluxos, „Revista Crítica de Ciências Sociais”, 73, 2005, http://rccs.revues. org/952, pdf, s. 4, [data dostępu: 20.08.2017].

${ }^{69}$ Zob. M. Gąsior, op. cit., s. 71-82.

${ }^{70}$ S. Royo, op. cit., pdf s. 22 i 24 oraz E. Dionísio, op. cit., pdf, s. 57.

${ }^{71}$ S. Royo, op. cit., pdf, s. 15 i 17 oraz M. Abranches (2008), INTI Project: One-Stop Shop: A New Answer for Immigrant Integration?, JLS/2006/INTI/148, Country Report for Portugal, http://www.oss. inti.acidi.gov.pt/index.php?option=com_docman\&task=cat_view\&gid=65\&Itemid=57\&lang=en, pdf s. 3, [data dostępu: 20.04.2011]. Procent imigrantów mających zezwolenie na pobyt w Portugalii w odniesieniu do tamtejszej populacji w 2003 r. został obliczony przez autorkę. Zob. Relatório de Actividades 2006. Imigração, Fronteiras e Asilo, Serviço de Estrangeiros e Fronteiras (SEF), http://sefstat. sef.pt/Docs/Rifa_2006.pdf, pdf, s. 11, [data dostępu: 08.08.2017] i Instituto Nacional de Estatística, https://www.ine.pt/xportal/xmain?xpid=INE\&xpgid=ine_indicadores\&indOcorrCod=0003942\&contexto $=$ bd\&selTab $=$ tab2, [data dostępu: 08.08.2017].

${ }^{72}$ J. Peixoto, C. Sabino, A. Abreu (2009), Immigration Policies in Portugal: Limits and Compromise in the Quest for Regulation, „European Journal of Migration and Law”, Vol. 11, https://extranet. uj.edu.pl/ehost/pdfviewer/,DanaInfo=web.ebscohost.com +pdfviewer?vid=5\&hid= $\overline{107 \& s i d=589 f 4 c}$ 4a-95d6-4a0c-bf9f-4ce1f105101f\%40sessionmgr113, pdf s. 2, [data dostępu: 30.05.2013] i S. Royo, op. cit., pdf, s. 20. 
z lat 1982-1992, oprócz m.in. kolejnego kryzysu naftowego, zapewne znajdowały się bariery stwarzane przez pierwsze portugalskie regulacje imigracyjne ${ }^{73}$.

Brak tradycji imigracyjnej Portugalii przejawiał się m.in. w pobieżnym traktowaniu tego aspektu w portugalskim ustawodawstwie. Pierwszym aktem prawnym dotyczącym imigracji był dekret z mocą ustawy z $1981 \mathrm{r}$. Jednak polityka imigracyjna prowadzona przez Portugalię w latach 80 . XX w. w zasadzie ograniczała się do jednej kwestii - regulacji napływających strumieni. Wdrażanie założeń tak pojmowanej polityki imigracyjnej zostało włączone w zakres kompetencji - istniejącego od 1976 r. i podlegającego Ministerstwu Spraw Wewnętrznych - Urzędu ds. Cudzoziemców i Granic (Serviço de Estrangeiros e Fronteiras - SEF). Co więcej, polityka ta nie okazała się efektywna, o czym świadczył stały wzrost liczby nieudokumentowanych imigrantów ${ }^{74}$. Szacuje się, że w latach 90 . XX w. na obszarze Portugalii mogło przebywać nawet do 75 tys. cudzoziemców o nieuregulowanym statusie $^{75}$. Wymownym potwierdzeniem wskazanej nieskuteczności ówczesnej portugalskiej polityki imigracyjnej było sięgnięcie przez tamtejsze władze do rozwiązania ekstraordynaryjnego. Miało ono na celu umożliwienie uregulowania statusu osiadłym w Portugalii nieudokumentowanym imigrantom. Za sprawą postanowień dekretu z mocą ustawy z 1992 r. ok. 39 tys. osób uzyskało zezwolenie na pobyt ${ }^{76}$. Jednak konieczność zastosowania tego nadzwyczajnego środka nie przyczyniła się do zmiany założeń portugalskiej polityki imigracyjnej w kolejnych latach. Zapisy dekretu z mocą ustawy z 1993 r., podobnie jak postanowienia wspomnianego dokumentu z 1981 r., były wyrazem postrzegania imigrantów w kategoriach czasowych. Nie widziano w przybywających do pracy cudzoziemcach potencjalnych współobywateli ${ }^{77}$. Nadto zamierzano $\mathrm{w}$ jak największym stopniu zahamować proces osiadania imigrantów w Portugalii na stałe. Jak podkreśliła Maria Ioannis Baganha, celem realizowanej wówczas polityki była „zerowa imigracja” (imigração zero). Realia jednakże nie sprostały oczekiwaniom decydentów. Napływający coraz liczniejszymi strumieniami obcokrajowcy, szczególnie z terenów portugalskojęzycznych, przedostawali się do Portugalii, korzystając $\mathrm{z}$ wiz krótkiego pobytu, by po ich wygaśnięciu pozostać tam wbrew prawu ${ }^{78}$. Tym samym „portugalska polityka imigracyjna w dalszym ciągu nie przynosiła pozytywnych rezultatów dla żadnej ze stron. Rozwój szarej strefy równocześnie pozbawiał portugalski budżet części wpływów podatkowych, a imigrantom fundował życie w ciągłej niepewności”79. W efekcie, aby umożliwić pracującym cudzoziemcom uregulowanie ich statusu,

\footnotetext{
${ }^{73}$ S. Royo, op. cit., pdf, s. 16-17.

${ }_{74}$ J. Peixoto, C. Sabino, A. Abreu, op. cit., pdf, s. 3.

75 S. Royo, op. cit., pdf, s. 18.

76 J. Peixoto, C. Sabino, A. Abreu, op. cit., pdf, s. 4.

77 Ibid.

${ }_{78}$ M.I. Baganha, Política de imigração..., pdf s. 5.

${ }^{79}$ M. Gąsior, op. cit., s. 76.
} 
musiano ponownie odwołać się do rozwiązań nadzwyczajnych ${ }^{80}$. Niemniej w latach 1995-1998 można już zauważyć „pierwsze symptomy zmiany dotychczasowego postrzegania zjawiska imigracji. Stopniowo odchodzono od strategii niemal wyłącznego koncentrowania się na regulacji przepływu cudzoziemców, dostrzegając potrzebę działań integracyjnych" ${ }^{81}$. Kończąc nakreślanie historii migracyjnej Portugalii warto jeszcze dodać, że pod koniec lat 90. XX w. przyszło jej się zmierzyć z nowym wyzwaniem. Był nim napływ znacznej liczby migrantów z Europy Wschodniej ${ }^{82}$, zwłaszcza z Ukrainy ${ }^{83}$, czyli z obszaru historycznie i kulturowo (w tym językowo) z Portugalią niepowiązanego ${ }^{84}$.

Przechodząc do polskich doświadczeń, zasadnym wydaje się tutaj odwołanie do dokumentu Rady Ministrów Polityka migracyjna Polski z 2012 r., zgodnie z którym „(...) Polska nie miała ani czasu, ani możliwości tworzenia i planowania własnej polityki migracyjnej w naturalnym cyklu, charakterystycznym dla tych państw europejskich, które posiadają wieloletnią tradycję w zakresie przyjmowania migrantów" ${ }^{85}$. (Pomimo braku sprecyzowania w tym dokumencie, o jakie państwa europejskie chodzi, w pełni zasadnym wydaje się uznanie, że nie zalicza się do nich Portugalii.) Jak zostało podkreślone w przywoływanym dokumencie, na początku lat 90. XX w. Polsce przyszło się zmierzyć z kilkoma wyzwaniami migracyjnymi, na które nie była przygotowana. Wówczas to bowiem „Polska po raz pierwszy od czasów II wojny światowej zetknęła się z globalnymi przepływami migracyjny-

${ }^{80}$ Zob. M.I. Baganha, Política de imigração..., pdf. s. 6 i J. Peixoto, C. Sabino, A. Abreu, op. cit., pdf, s. 4.

${ }^{81}$ M. Gąsior, op. cit., s. 77. Zob. też J. Peixoto, C. Sabino, A. Abreu, op. cit., pdf, s. 4-5.

${ }^{82}$ Wcześniej, do połowy lat 80. XX w. - uznając r. 1974 za przełomowy dla portugalskiej historii migracyjnej - jak już zostało wspomniane, na terytorium Portugalii przybywała głównie ludność z byłych kolonii, zwłaszcza z Wysp Zielonego Przylądka, Angoli, Mozambiku i Gwinei Bissau. Po wejściu Portugalii do EWG w 1986 r. w dalszym ciągu napływały do tego kraju strumienie migracyjne historycznie i kulturowo z nim związane - przede wszystkim z obszarów afrykańskich i z Brazylii, która mierzyła się wówczas z kryzysem ekonomicznym. J. Peixoto, C. Sabino, A. Abreu, op. cit., pdf s. 2-3 i S. Royo, op. cit., pdf, s. 20.

${ }^{83}$ W 1999 r. zezwolenie na pobyt w Portugalii miało 127 Ukraińców, a w 2002 r. - 65,5 tys. Tym samym w ciągu trzech lat ich liczba wzrosła ponad 400 razy. (Należy jednak zauważyć, że zapisem dekretu z mocą ustawy z 2001 r. wprowadzono w Portugalii, funkcjonujący do 2003 r., szczególny mechanizm regulowania statusu imigrantów (autorização de permanência.) Pozwalał on na udzielanie zezwoleń na pobyt cudzoziemcom już przebywającym na obszarze Portugalii za okazaniem umowy o pracę. Można zatem przypuszczać, że znaczny odsetek ze wspomnianej liczby 65,5 tys. stanowili Ukraińcy dotychczas pracujący na obszarze Portugalii nielegalnie.) I. Yeleyko, Specyfika migracji zarobkowej ludności na Ukrainie, http://ur.edu.pl/pliki/Zeszyt11/30.pdf, pdf s. 7, [data dostępu: 20.08.2017].

${ }^{84}$ Zob. J. Peixoto (2009), New Migrations in Portugal: Labour Markets, Smuggling and Gender Segmentation, „International Migration” Vol. 47 (3), https://extranet.uj.edu.pl/ehost/pdfviewer/,Da $\underline{\text { naInfo=web.a.ebscohost.com }+ \text { pdfviewer } ? \text { vid }=8 \& \text { sid }=228649 \mathrm{~b} 4-30 \mathrm{~b} 3-40 \mathrm{ed}-\mathrm{b} 691 \text {-ed } 1898 \mathrm{eb} 6 \mathrm{a} 5 \mathrm{f} \% 40}$ sessionmgr4004\&hid=4106,pdf, s. 8, [data dostępu: 15.07.2016].

${ }^{85}$ Polityka migracyjna Polski - stan obecny i postulowane działania. Dokument przyjęty przez Radę Ministrów 31 lipca 2012 r., Warszawa 2012, s. 5. 
mi (...)" ${ }^{\prime 6}$. Stała się zarówno krajem tranzytowym, jak i docelowym dla określonych grup imigrantów. Do Polski udawali się zwłaszcza mieszkańcy obszarów byłego ZSRR, Wietnamczycy i Romowie. Wtedy też w naszym kraju zaczęly się kształtować imigranckie społeczności, z których do najbardziej licznych aktualnie należą: ormiańska, wietnamska, ukraińska i białoruska. Ponadto w 1990 r. miał również miejsce napływ na terytorium naszego państwa uchodźców. Zaś doświadczającej transformacji ustrojowej Polsce brakowało odpowiednich regulacji i procedur koniecznych dla efektywnego i korzystnego dla obu stron zarządzania zjawiskiem imigracji ${ }^{87}$. Zarysowana sytuacja zdaje się być wystarczająco podobna do okoliczności, w jakich znajdowała się szczególnie od lat 80. XX w. Portugalia. Naznaczona czasami Nowego Państwa i zmagająca się, bez wcześniejszego przygotowania, z kolejnymi zaskakującymi dla niej wyzwaniami imigracyjnymi.

Warto nadmienić, że uzasadnienie analizy porównawczej Polski i Portugalii $\mathrm{w}$ zakresie zagadnień migracyjnych znajdujemy w zaproponowanej przez M. Duszczyka typologii modeli realizacji polityki migracyjnej. Spośród pięciu wyszczególnionych przez niego modeli, zasadnym zdaje się tutaj przywołanie dwóch: modelu kolonialno-humanitarnej polityki migracyjnej oraz nowych państw imigracyjnych $^{88}$. Co istotne, Portugalia mieści się $\mathrm{w}$ ramach drugiego $\mathrm{z}$ wymienionych modeli, który, jak sama nazwa wskazuje, skupia państwa o relatywnie krótkiej historii imigracyjnej. Zgodnie z oceną polskiego naukowca, państwa wpisujące się $\mathrm{w}$ ten model wyróżnia m.in. dość liberalne stanowisko wobec zjawiska imigracji, niemniej priorytetem ich jest pokrywanie zapotrzebowania na rynku pracy. Zaś z perspektywy aktualnej pozycji Polski, zgodnie z obserwacjami M. Duszczyka, to właśnie doświadczenia krajów przystających do modelu nowych państw imigracyjnych (obok doświadczeń krajów modelu komplementarnej polityki migracyjnej) wydają się najbardziej użyteczne dla wypracowania polskiej spójnej polityki migracyjnej. Jednocześnie, w kontekście nakreślanego potencjału porównawczego omawianych państw, wymowne jest już samo niewpisywanie się Portugalii w model kolonialno-humanitarnej polityki migracyjnej. Model, którego właściwość w pierwszym rzędzie zasadza się na przyznawaniu szczególnych praw migrantom z określonych terytoriów ${ }^{89}$.

${ }^{86}$ Ibid.

87 Ibid.

${ }^{88}$ Oprócz wymienionych, M. Duszczyk wskazuje następujące modele polityki migracyjnej: model komplementarnej polityki migracyjnej (zorientowanej na rynek pracy), model rezydualnej (asymilacyjnej) polityki migracyjnej i model wielokulturowej polityki migracyjnej. Zob. M. Duszczyk (2008), Wyzwania polskiej polityki migracyjnej a doświadczenia międzynarodowe, w: P. Kaczmarczyk, M. Okólski (red.) Polityka migracyjna jako instrument promocji zatrudnienia i ograniczenia bezrobocia, Warszawa: Ośrodek Badań nad Migracjami UW, s. 13-17.

${ }^{89}$ Chodzi tutaj przede wszystkim o byłe kolonie, ale nie tylko. M. Duszczyk zaznacza, że stosowanie preferencji wobec przybyszów z danych obszarów niekoniecznie musi mieć swoje źródło $\mathrm{w}$ tradycji kolonialnej, ale może też wypływać z innych przesłanek o charakterze historycznym, jako przykład podając Niemcy. Ibid., s. 15. 
Tym samym - chociaż jak wspomniano wcześniej, doświadczenia kolonialne Portugalii nie pozostają bez wpływu na obejmujące ten kraj strumienie migracyjne kolonializm nie stanowi głównego punktu odniesienia dla realizacji portugalskiej polityki migracyjnej ${ }^{90}$. Choć trzeba dodać, że Portugalii nie jest obce preferencyjne traktowanie osób pochodzących z krajów portugalskojęzycznych. Jako przykład może posłużyć - wprowadzone na mocy ustawy z $1994 \mathrm{r}^{91}$, a zniesione zapisem ustawy organicznej z 2006 r. $^{92}$ - postanowienie różnicujące $\mathrm{w}$ zakresie wymogu domicylu, jednego $\mathrm{z}$ warunków, od wypełnienia którego zależało nabycie portugalskiego obywatelstwa. I tak przed wystąpieniem z wnioskiem o naturalizację migrant pochodzący z kraju portugalskojęzycznego musiał mieszkać na terytorium Portugalii co najmniej 6 lat, a z każdego innego - nie mniej niż 10 lat ${ }^{93}$.

Przystępując do przedstawienia ujętych przez R. Matyję, A. Siewierską-Chmaj i K. Pędziwiatra w czterech postulatach głównych założeń polskiej doktryny imigracyjnej - w ramach których to postulatów mieszczą się wyzwania polityki imigracyjnej Polski - w pierwszej kolejności wskazanym wydaje się dookreślenie w omawianym kontekście pojęcia „doktryna” oraz „polityka”. Przyjmując zatem sposób definiowania powyższych terminów przez M. Duszczyka, doktrynę migracyjną pojmuje się jako „(...) fundamentalną zasadę polityki migracyjnej - filozofię państwa odwołującą się do strategicznych przesłanek cywilizacyjnych i modernizacyjnych lub tradycji narodowych czy podstawowych dokumentów międzynarodowych” ${ }^{94}$. A za politykę migracyjną uznaje się „(...) katalog instrumentów prowadzonych i kreowanych przez państwo lub jego części składowe, obejmujący zarówno bierne, jak i aktywne formy zarządzania imigracją i emigracją" ${ }^{35}$. (Ze względu na poruszoną $\mathrm{w}$ tym artykule problematykę, przywołane pojęcia będą stosowane jedynie w odniesieniu do zjawiska imigracji, z pominięciem emigracji.)

Podkreślając specyfikę i użyteczność przytoczonej definicji terminu „doktryna"96, trzej wymienieni wyżej naukowcy formułują cztery nadrzędne wytyczne

90 Ibid., s. 15-17.

${ }^{91}$ Lei n. ${ }^{\circ}$ 25/94 de 19 de Agosto, Altera a Lei n. ${ }^{\circ}$ 37/81 de 3 de Outubro (Lei da Nacionalidade), Assembleia da República, http://www.pgdlisboa.pt/leis/lei_mostra_articulado.php?nid=614\&tabela=lei_velhas\&nversao=2\&so_miolo, art. 6 ust. 1b, [data dostępu: 20.06.2018].

${ }^{92}$ Lei Orgânica n. ${ }^{\circ}$ 2/2006 de 17 de Abril, Altera a Lei n. ${ }^{\circ}$ 37/81 de 3 de Outubro (Lei da Nacionalidade), Assembleia da República, http://www.pgdlisboa.pt/leis/lei_mostra_articulado.php?ni-

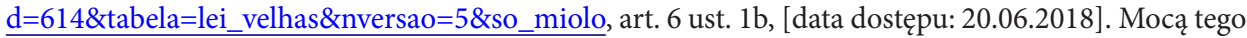
aktu prawnego portugalskie władze ujednoliciły wymóg domicylu (co najmniej 6 lat) dla wszystkich cudzoziemców chcących naturalizować się w Portugalii, niezależnie od kraju ich pochodzenia.

93 Lei n. ${ }^{\circ}$ 25/94 de 19 de Agosto..., art. 6, ust. 1 b.

${ }_{94}$ M. Duszczyk, op. cit., s. 12.

95 Ibid.

96 „Duszczyk posługuje się pojęciem doktryny w sposób wykraczający poza ujęcie czysto prawne, rozciągając je de facto na utrwalone praktyki czy kryteria stosowności, respektowane przez instytucje publiczne Rzeczypospolitej Polskiej. Zaletą takiego ujęcia jest możliwość przyciągania imigrantów - jako przybyszów na stałe - względnie stabilnymi, zakorzenionymi ustrojowo i in- 
polskiej doktryny imigracyjnej. Pierwsza z nich dotyczy wypływającej zarazem z dziejowego doświadczenia i politycznej tradycji I Rzeczypospolitej, powinności udzielania ochrony uchodźcom politycznym. Druga - obejmuje organizację repatriacji (nieograniczonej do osób ze Wschodu). Trzecia - odnosi się do przyjęcia otwartej postawy, celem dostrzeżenia w nich potencjalnych współobywateli, zarówno wobec obywateli innych europejskich krajów, jak i pozostałych obszarów bliskich Europie pod względem kulturowym. Czwarta z kolei - związana jest z przyciąganiem do Polski, przez stwarzanie im m.in. dogodnych warunków osiedlenia, wysokokwalifikowanych cudzoziemców ${ }^{97}$. Przy czym należy przypomnieć, że w artykule tym poszczególne doktryny stanowią przede wszystkim punkt wyjścia do omówienia konkretnych portugalskich rozwiązań o charakterze politycznym w omawianym zakresie.

Obecnie, w kontekście prowadzonej - tak na szczeblu Unii Europejskiej, jak i poszczególnych państw członkowskich - debaty publicznej, przedmiotem której są napływający do Europy uchodźcy, pierwszy z przedstawionych powyżej postulatów fundamentalnych założeń polskiej doktryny imigracyjnej wydaje się nabierać szczególnego znaczenia. Przy czym, jak zauważają R. Matyja, A. Siewierska-Chmaj i K. Pędziwiatr, to właśnie podjęcie kwestii tyczących się pomocy uchodźcom stanowiło zaczątek polskiej polityki migracyjnej po r. $1989^{98}$.

Aktualnie, jak się zdaje - zgodnie z konkluzją zawartą w dokumencie Rady Ministrów z 2012 r. - „[s]pecyficzne uwarunkowania związane ze stosowaniem prawa międzynarodowego oraz dorobku prawnego UE w postępowaniach dotyczących udzielania cudzoziemcom ochrony międzynarodowej powodują, że Polska ma w tym obszarze ograniczone możliwości kreowania własnej polityki, zarówno w zakresie admisji tej kategorii cudzoziemców, jak i tworzenia i stosowania własnych rozwiązań proceduralnych. W tym kontekście należy podkreślić kluczową z punktu widzenia Konwencji Genewskiej z 1951 r. zasadę non refoulement, czyli zasadę niewydalania i niezawracania uchodźców do kraju, w którym mogliby doświadczyć prześladowań oraz zasadę pełnego dostępu cudzoziemców do procedury o nadanie statusu uchodźcy" ${ }^{\prime 9}$. Tymczasem w Polsce trwają prace nad projektem nowelizacji ustawy o udzielaniu cudzoziemcom ochrony na terytorium RP z 13 czerwca 2003 r. ${ }^{100}$ oraz

stytucjonalnie regulacjami”. R. Matyja, A. Siewierska-Chmaj, K. Pędziwiatr (2015), Polska polityka migracyjna. W poszukiwaniu nowego modelu, Warszawa-Rzeszów: Wydawnictwa Uniwersytetu Warszawskiego, s. 17.

97 Ibid.

${ }_{98}$ Ibid, s. 70.

99 Polityka migracyjna Polski..., s. 64.

100 Zob. Ustawa o zmianie ustawy o udzielaniu cudzoziemcom ochrony na terytorium Rzeczypospolitej Polskiej oraz niektórych innych ustaw, projekt z dnia 30 stycznia 2017 r., https://bip.mswia. gov.pl/bip/projekty-aktow-prawnyc/2017/24478,Projekt-ustawy-o-zmianie-ustawy-o-udzielaniucudzoziemcom-ochrony-na-terytorium-.html, [data dostępu: 21.07.2017] i Ustawa $z$ dnia 13 czerwca 2003 r. o udzielaniu cudzoziemcom ochrony na terytorium Rzeczypospolitej Polskiej. Dz. U. 2003, nr 128, poz. 1176. Por. Ustawa o zmianie ustawy o udzielaniu cudzoziemcom ochrony na terytorium 
innych ustaw ${ }^{101}$. Opierając się zaś na stanowisku Helsińskiej Fundacji Praw Człowieka, sformułowane w tym projekcie postanowienia dotyczące uchodźców „mogą prowadzić do systemowego naruszania ich praw zawartych w Konwencji Genewskiej z 1951 r. i prawie międzynarodowym"102. Ponadto wskazana organizacja wyraża również obawę co do zgodności proponowanych rozwiązań legislacyjnych z prawem UE. Szczególne zaniepokojenie Helsińskiej Fundacji Praw Człowieka wzbudza m.in. propozycja zaprowadzenia tzw. procedur granicznych, listy bezpiecznych krajów trzecich i listy bezpiecznych krajów pochodzenia, brak zapewnienia skutecznego środka odwoławczego od decyzji nieprzyznania ochrony oraz ewentualność pozbawienia, w sposób automatyczny, wolności wielu występujących o udzielenie międzynarodowej ochrony w Polsce cudzoziemców ${ }^{103}$. Zbieżne stanowisko wobec przywołanego projektu nowelizacji ustawy m.in. zajęli również: Wysoki Komisarz Narodów Zjednoczonych ds. Uchodźców (UNHCR) i Stowarzyszenie Amnesty International ${ }^{104}$. (W momencie oddania tego artykułu do druku proces legislacyjny omawianego projektu nowelizacji ustawy o udzielaniu cudzoziemcom ochrony na terytorium RP z 13 czerwca 2003 r. nie został zakończony.)

Podobnie jak w przypadku Polski, kształtowanie polityki przyjmowania uchodźców w Portugalii ${ }^{105}$ nie może być wolne od ponadpaństwowych zobowiązań.

Rzeczypospolitej Polskiej oraz niektórych innych ustaw, projekt z dnia 13 czerwca 2017 r., https:// bip.mswia.gov.pl/bip/projekty-aktow-prawnyc/2017/24478,Projekt-ustawy-o-zmianie-ustawy-oudzielaniu-cudzoziemcom-ochrony-na-terytorium-.html, [data dostępu: 21.07.2017].

${ }_{101}$ M.in. Ustawa z dnia 12 grudnia 2013 r. o cudzoziemcach. Dz. U. 2013, poz. 1650.

${ }^{102}$ Helsińska Fundacja Praw Człowieka, Propozycja zaostrzenia przepisów wobec uchodźców wciąż aktualna - kolejne stanowisko HFPC do projektu nowelizacji ustawy, http://www.hfhr.pl/ propozycja-zaostrzenia-przepisow-wobec-uchodzcow-wciaz-aktualna-kolejne-stanowisko-hfpc-doprojektu-nowelizacji-ustawy/, [data dostępu: 21.07.2017].

${ }^{103}$ Ibid. Zob. też Uwagi Helsińskiej Fundacji Praw Człowieka do projektu ustawy o zmianie ustawy o udzielaniu cudzoziemcom ochrony na terytorium Rzeczypospolitej Polskiej oraz niektórych innych ustaw (projekt $z$ dnia 30 stycznia 2017 r.), http://www.hfhr.pl/wp-content/uploads/2017/02/HFPC-uwagi-do-projektu-zmiany-ust-o-ochronie-14-02-2017.pdf, [data dostępu: 21.07.2017].

${ }^{104}$ Zob. Uwagi Wysokiego Komisarza Narodów Zjednoczonych ds. Uchodźców (UNHCR) i Uwagi Stowarzyszenia Amnesty International, https://bip.mswia.gov.pl/bip/projekty-aktow-prawnyc/2017/ 24478, Projekt-ustawy-o-zmianie-ustawy-o-udzielaniu-cudzoziemcom-ochrony-na-terytoriumhtml, [data dostępu: 21.07.2017].

${ }^{105}$ Zgodnie z danymi udostępnianymi przez Urząd do Spraw Cudzoziemców, w 2017 r. z największą liczbą wniosków o udzielenie ochrony międzynarodowej na terytorium Polski wystąpili obywatele Rosji, Ukrainy i Tadżykistanu. (Nie sposób tutaj jednak nie wspomnieć o naruszaniu przez nasze państwo prawa cudzoziemców do ubiegania się o międzynarodową ochronę, uniemożliwiając im złożenie tego rodzaju wniosków na wschodniej granicy.) Zaś według danych Urzędu ds. Cudzoziemców i Granic najwięcej wniosków o udzielenie ochrony międzynarodowej w Portugalii w r. 2016 złożyli obywatele Syrii, Iraku, Pakistanu, Afganistanu i Chin. Urząd do Spraw Cudzoziemców, Podsumowanie: ochrona międzynarodowa w 2017 r., 18.01.2018, https://udsc.gov.pl/podsumowanie-ochrona-miedzynarodowa-w-2017-roku/, [data dostępu: 20.06.2018], Relatório de Imigração, Fronteiras e Asilo 2016, Serviço de Estrangeiros e Fronteiras (SEF), https://sefstat.sef.pt/Docs/Rifa2016. pdf, pdf s. 46, [data dostępu: 20.06.2018] i Helsińska Fundacja Praw Człowieka, Prawa cudzoziem- 
Zarówno regulująca omawianą materię portugalska ustawa z r. $2008^{106}$, jak i przeprowadzona w r. $2014^{107}$ jej nowelizacja pozostają w ścisłym związku z procesem ujednolicania polityk państw członkowskich UE oraz tworzenia europejskiego systemu przyjmowania uchodźców ${ }^{108}$. Uwarunkowania o charakterze ponadpaństwowym w praktyce nie wykluczają jednak, co jest obecnie wyraźnie widoczne w Polsce, podejmowania na poziomie krajowym prób wprowadzania własnych procedur godzących $\mathrm{w}$ międzynarodowe standardy ochrony praw uchodźców. Co więcej - zważywszy, że europeizacja prawa w obszarze migracji wiąże się obecnie z rozszerzaniem kontroli i kryminalizacji ${ }^{109}$ - konieczność transpozycji unijnych dyrektyw może stanowić dobry pretekst dla wdrożenia „ponadprogramowych" ograniczeń praw omawianej kategorii osób. Także i Portugalia nie okazała się w pełni odporna na tego rodzaju zakusy. Konsultując wstępny projekt nowelizacji ustawy z 2008 r., pozarządowa organizacja Portugalska Rada ds. Uchodźców (Conselho Português para os Refugiados - CPR) oraz UNHCR wyrażały obawy co do określonych zapisów tego projektu, które „(...) zagrażały pełnemu stosowaniu Konwencji Genewskiej z 1951 r. dotyczącej statusu uchodźców oraz odnoszącego się do uchodźców zasad prawa międzynarodowego, a także praw człowieka oraz prawa humanitarnego, stanowiąc jednocześnie odrzucenie zasad określonych w ustawie z r. 2008"110. Co jednak warte podkreślenia, portugalscy decydenci przychylili się do części zgłaszanych przez wspomniane organizacje postulatów, spośród których można wskazać m.in. „wyraźne ograniczenie sytuacji, w których zatrzymywane są ubiegające się o ochronę osoby małoletnie bez opieki” ${ }^{111}$.

ców poszukujących ochrony w Polsce nie są przestrzegane, 26. 02. 2018, http://www.hfhr.pl/prawacudzoziemcow-poszukujacych-ochrony-w-polsce-nie-sa-przestrzegane/, [data dostępu: 20.06.2018]. Zob. też Helsińska Fundacja Praw Człowieka, Co wynika $z$ danych o udzielaniu ochrony międzynarodowej w Polsce w 2017 roku?, 22.01.2018, http://www.hfhr.pl/co-wynika-z-danych-o-udzielaniuochrony-miedzynarodowej-w-polsce-w-2017-roku/, [data dostępu: 20.06.2018].

${ }^{106}$ Zob. Lei n. ${ }^{\circ}$ 27/2008 de 30 de Junho, Assembleia da República, Diário da República, 1. a série N. ${ }^{\circ} 124$ - 30 de Junho de 2008, https://dre.pt/application/dir/pdf1s/2008/06/12400/0400304018. pdf\#1, [data dostępu: 20.07.2017].

${ }^{107}$ Zob. Lei n. ${ }^{\circ}$ 26/2014 de 5 de maio, Assembleia da República, Diário da República, 1. ${ }^{\text {a }}$ série N.o 85 - 5 de maio de 2014, https://dre.pt/application/dir/pdf1sdip/2014/05/08500/0260602637. pdf\#1, [data dostępu: 20.07.2017].

${ }^{108}$ L. Sousa, P. M. Costa (2016), A evolução do direito de asilo e regimes de proteção a refugiados em Portugal (1975-2015), Centro de Estudos Judiciários, https://repositorioaberto.uab.pt/ bitstream/10400.2/5524/1/costa_sousa_A\%20evolu\%C3\%A7\%C3\%A3o\%20do\%20direito\%20de\%20 asilo\%20e\%20regimes\%20de\%20prote\%C3\%A7\%C3\%A3o\%20a\%20refugiados\%20em\%20Portugal. pdf, pdf s. 19 - 21, [data dostępu: 21.07.2017].

109 B. Padilla, T. França (2016), Migration Policies and Institutional Frameworks. Development and Evolution in Portugal, Comparative Cultural Studies: European and Latin America Perspectives 1, http:// www.fupress.net/index.php/ccselap/article/view/19987/18624, pdf, s. 42-43, [data dostępu: 20.07.2014].

${ }_{110}$ Conselho Português para os Refugiados (2014), Relatório de Atividades, http://refugiados. net/1cpr/www/RelatorioCPR2014.pdf, pdf, s. 6, [data dostępu: 20.07.2014].

111 Ibid. 
Przechodząc do drugiego z proponowanych założeń, mających stanowić podstawę polskiej doktryny imigracyjnej, należy zauważyć, że R. Matyja, A. Siewierska-Chmaj i K. Pędziwiatr rozważają rozszerzenie kategorii osób, które mogłyby zostać wzięte pod uwagę podczas kreowania nowej strategii repatriacyjnej. Według wspomnianych naukowców oferta związana z powrotem do kraju, oprócz Polaków ze Wschodu, mogłaby zostać skierowana do przedstawicieli dawnej migracji (zarówno o charakterze politycznym, jak i ekonomicznym) na Zachód. Nadto powinno się rozpatrzyć wypracowanie rozwiązań ułatwiających powrót osobom, które wyjechały z Polski już po wstąpieniu do UE ${ }^{112}$. Ze względu na specyfikę polskiej akcji repatriacyjnej, obejmującej reemigrantów ze Wschodu, kwestia ta, choć bez wątpienia istotna, zostanie w tym artykule pominięta. (Przy czym można nadmienić, że po rewolucji goździków z 1974 r. portugalskie władze prowadziły działania polityczne ukierunkowane na wspomnianych już retornados.) Natomiast przybliżone tutaj zostaną podejmowane obecnie w Portugalii działania, których celem jest wspieranie osób decydujących się na powrót do ojczyzny i udzielanie im pomocy w procesie ponownego włączania się w portugalskie społeczeństwo. W reakcji na masową emigrację wywołaną kryzysem ekonomicznym, który sparaliżował Portugalię pod koniec pierwszej dekady XXI wieku, działania tego rodzaju zostały ujęte w przyjętej 20 marca 2015 r. przez tamtejszą Radę Ministrów Strategii dla migracji na lata $2015-2020^{113}$.

Wpisanie w portugalską politykę migracyjną, i to w tak szerokim zakresie, zagadnień związanych $\mathrm{z}$ reemigracją znalazło swoje odzwierciedlenie $\mathrm{w}$ sferze instytucjonalnej. W miejsce powołanej w 2007 r. Wysokiej Komisji ds. Imigracji i Dialogu Międzykulturowego (Alto Comissariado para a Imigração e Diálogo Intercultural) powstała Wysoka Komisja ds. Migracji (Alto Comissariado para as Migrações $)^{114}$. Jak wskazuje nazwa tej podlegającej bezpośrednio Radzie Ministrów instytucji, m.in. sygnowana przez nią rozbudowana witryna internetowa dostarcza użytecznych informacji nie tylko przybyłym do Portugalii imigrantom, ale i rozważającym powrót do ojczyzny portugalskim emigrantom. W witrynie tej można

112 R. Matyja, A. Siewierska-Chmaj, K. Pędziwiatr, op. cit., s. 18.

113 Zob. Plano Estratégico para as Migrações (2015-2020), Resolução do Conselho de Ministros n. ${ }^{\circ}$ 12-B/2015, Diário da República, 1. ${ }^{a}$ série - N. ${ }^{\circ} 56-20$ de março de 2015, http://www. acm.gov.pt/documents/10181/42225/Plano+Estrat\%C3\%A9gico+para+as+Migra\%C3\%A7\%C3\%B5es+\%28PEM\%29_RCM.pdf/b6375f51-53e2-4d88-9783-81cf1c7bb91c, pdf s. 22 - 23, [data dostępu: 19.07.2017]. Dokument ten jest również dostępny w jęz. angielskim: Strategic Plan for Migration, Resolution of the Council of Ministers No. 12-B/2015, on 20 March, http://www.acm.gov.pt/ documents/10181/222357/PEM_ACM_final.pdf, [data dostępu: 19.07.2017].

${ }_{114}$ Początkowo funkcjonował ustanowiony w 1996 r. Wysoki Komisarz ds. Imigracji i Mniejszości Etnicznych (Alto-Comissário para a Imigração e Minorias Étnicas), następnie na jego miejsce w 2002 r. powołano Wysoką Komisję ds. Imigracji i Mniejszości Etnicznych (Alto Comissariado para a Imigração e Minorias Étnicas), która w 2007 r. została zastąpiona przez wspomnianą Wysoką Komisję ds. Imigracji i Dialogu Międzykulturowego (Alto Comissariado para a Imigração e Diálogo Intercultural). 
np. dowiedzieć się, jakich formalności należy dopełnić, aby uczące się za granicą dziecko mogło bez trudności kontynuować naukę na analogicznym poziomie w Portugalii ${ }^{115}$.

Tutaj należy zauważyć, że w Polsce w ramach projektu Zielona Linia. Centrum Informacyjno-Konsultacyjne Służb Zatrudnienia funkcjonuje witryna internetowa powroty.gov.pl, w której można odnaleźć przydatne informacje dotyczące reemigracji.

Wracając do Portugalii, zgodnie z przywołanym powyżej dokumentem pt. Strategia dla migracji z 2015 r., rozpowszechnianie kompleksowych informacji związanych z powrotem do kraju i reintegracją w portugalskim społeczeństwie należy ponadto do Biur Wspierania Emigrantów (Gabinetes de Apoio ao Emigrante). Pierwsze z nich powstały już na początku XXI w., ale na lata 2015-2020 zaplanowano rozbudowywanie ich sieci ${ }^{116}$. Biura te - których działania kierowane są również do Portugalczyków dopiero zamierzających emigrować, celem dostarczenia im informacji odnośnie do praw, jakie przysługują im w krajach przyjmujących - każdorazowo tworzone są na mocy odrębnej umowy. Porozumienia tego rodzaju zawierają między sobą: Generalna Dyrekcja ds. Konsularnych i Portugalskich Wspólnot (Direç̧ão-Geral dos Assuntos Consulares e das Comunidades Portuguesas) i organ przedstawicielski danej gminy lub (taka możliwość istnieje od 2016 r.) określonej parafii, w której to ma zacząć funkcjonować Biuro Wspierania Emigrantów ${ }^{117}$. Przy czym należy uściślić, że chodzi tutaj o parafię (freguesia) będącą jednostką tamtejszego samorządu terytorialnego ${ }^{118}$. Aktualnie na obszarze Portugalii działa ponad sto Biur Wspierania Emigrantów ${ }^{119}$.

Nadto spośród nakreślonych w Strategii dla migracji z 2015 r. inicjatyw, mających na celu udzielanie pomocy reemigrantom $w$ procesie adaptowania się na nowo w portugalskim społeczeństwie, wartym przybliżenia wydaje się Program Mentorów dla Migrantów (Programa Mentores para Migrantes) ${ }^{120}$. Co więcej, ten koordynowany przez Wysoką Komisję ds. Migracji program - z którego mogą korzystać również imigranci i uchodźcy - zdaje się stwarzać dodatkową przestrzeń

115 Zob. Alto Comissariado para as Migrações (ACM), http://www.acm.gov.pt/-/estud-1, [data dostępu: 21.07.2017].

116 Plano Estratégico para..., pdf s. 23.

117 República Portuguesa, Ministro Dos Negócios Estrangeiros, Vão ser instalados os primeiros Gabinetes de Apoio ao Emigrante em fruegesias, http://www.portugal.gov.pt/pt/ministerios/mne/noticias/20161118-secp-emigrantes.aspx, [data dostępu: 19.07.2017].

118 Zob. Konstytucja Republiki Portugalskiej..., art. 236.

119 Zob. País ao Minuto, Governo alarga gabinetes de apoio aos emigrantes às juntas de freguesia, https://www.noticiasaominuto.com/pais/692260/governo-alarga-gabinetes-de-apoio-aos-emigrantes-as-juntas-de-freguesia, [data dostępu: 19.07.2017] i lista completa dos GAE, https://www.portaldascomunidades.mne.pt/images/GADG/Coordenadas_GAE_PORTAL_21_06_17_v4.pdf, [data dostępu: 19.07.2017]. Jak można jednak zauważyć, lista ta zawiera tylko Biura Wspierania Emigrantów funkcjonujące w ramach gmin.

120 Plano Estratégico para..., pdf s. 23. 
do nawiązywania głębszych relacji między migrantami (także przymusowymi) a Portugalczykami bez tego rodzaju osobistych doświadczeń. Mentorem bowiem może zostać każdy, kto w ramach wolontariatu zdecyduje się podzielić z migrantem swoją znajomością codziennego życia w portugalskim państwie bądź - jeżeli ma takie kompetencje - wiedzą ekspercką z danego obszaru. Przy czym migrant, znajdujący się w określonej sytuacji, zostaje skontaktowany z mentorem, który jest w stanie najlepiej odpowiedzieć na jego specyficzne potrzeby. Należy także odnotować, że pod koniec 2012 r. ruszył, trwający dwa lata, pilotaż tego programu. Jego efekty zaś - uczestniczący w projekcie pilotażowym migranci mieli pod kątem użyteczności ocenić go pozytywnie lub bardzo pozytywnie - pozwoliły na objęcie omawianym programem całego kraju i pozyskanie do współpracy nowych podmiotów (różnego rodzaju organizacji i stowarzyszeń, a także poszczególnych gmin). We wspomnianym okresie zainicjowano 31 procesów mentorskich. Spośród tych, które zostały wówczas w pełni zrealizowane, 9 było związanych z poszukiwaniem pracy, 4 mieściły się w obszarze zagadnień z zakresu przedsiębiorczości, 3 dotyczyły kwestii obywatelstwa, praw człowieka i międzykulturowości, a 5 odnosiło się m.in. do sposobów spędzania czasu wolnego i przekazywania ogólnych informacji ${ }^{121}$. Aktualnie działa witryna internetowa, za pomocą której - oprócz uzyskania niezbędnych informacji o programie - mogą rejestrować się zarówno poszukujący wsparcia migranci, jak i osoby chcące im pomocy udzielić. Przy tym rejestracja jest związana $\mathrm{z}$ wypełnieniem szeregu rubryk dotyczących danych osobowych, kwalifikacji, dyspozycyjności i obszarów (w jakich oczekuje się bądź można udzielić) wsparcia. W taki oto sposób powstają dwie bazy osób, z których w oparciu o udzielone podczas rejestracji informacje, jak już zostało wspomniane, łączy się migrantów o określonych potrzebach z mentorami o adekwatnych kompetencjach $^{122}$.

W odniesieniu do trzeciego z postulowanych przez polskich naukowców fundamentalnych założeń doktryny imigracyjnej Polski (którym jest „otwartość na obywateli krajów europejskich i pokrewnego Europie kręgu kulturowego jako

${ }^{121}$ Rede Comum de Conhecimento, Programa Mentores para Migrantes, http://www.rcc.gov.pt/ Directorio/Temas/ServicosCidadao/Paginas/Programa-Mentores-para-Migrantes.aspx, [data dostępu: 22.07.2017].

${ }_{122}$ Zob. https://mentores.acm.gov.pt/home, [data dostępu: 22.07.2017]. Warto wspomnieć, że w Portugalii realizowane są również inne interesujące projekty, których celem jest działanie na rzecz integracji imigrantów w społeczeństwie osiedlenia. Jednym z takich przedsięwzięć jest, zainicjowany w 2004 r. w Czechach, projekt znany pod nazwą Next Door Family. Portugalia dołączyła do niego w r. 2012 pod szyldem Família do Lado. Co roku w tym samym dniu odbywają się szczególne obiadowe spotkania. Główna zasada, na której opierają się te wydarzenia jest niezwykle prosta. Przy stole spotyka się rodzina imigrancka z portugalską (bądź np. w przypadku Czech - czeską). Niezależnie która z nich jest gospodarzem, przygotowuje wpisujący się w jej kulturę posiłek. Alto Comissariado para as Migrações (ACM), Família do Lado 2017, https://www.acm.gov.pt/-/familia-do-lado, [data dostępu: 20.06.2018]. 
potencjalnych sąsiadów i współobywateli” ${ }^{123}$ ), warto w pierwszym rzędzie nawiązać do sytuacji demograficznej obu zestawianych państw. I tak, według najnowszych przewidywań ONZ, Polska wpisuje się w poczet państw, w których spadek liczby ludności postępuje najszybciej. Jej populacja (która obecnie wynosi nieco ponad 38 mln) - obok Bułgarii, Chorwacji, Łotwy, Litwy, Mołdawii, Rumunii, Serbii i, co wydaje się z perspektywy Polski jako kraju przyjmującego szczególnie istotne, Ukrainy - do 2050 r. ma się zmniejszyć o ponad 15\%, a do r. 2100 o przeszło $44 \%$. W przypadku Portugalii (której populacja przekracza aktualnie $10 \mathrm{mln}$ ) prognozy przedstawiają się następująco: do r. 2050 liczba ludności tego kraju ma się skurczyć o niemal $13 \%$, a do r. 2100 o ponad $36 \%{ }^{124}$. Pomimo zauważalnego zróżnicowania przewidywanego tempa spadku populacji obu państw - jak i zróżnicowania wielkości ich populacji - trudno byłoby jednak zanegować wysoki stopień podobieństwa Polski i Portugalii w tym zakresie ${ }^{125}$.

Mając na uwadze powyższe można dodać, że - zgodnie z oceną zawartą w przygotowanym przez Eurostat regionalnym roczniku z 2016 r. - „chociaż mało prawdopodobnym zdaje się odwrócenie postępującego trendu, jakim jest starzenie się europejskich społeczeństw jedynie za sprawą migracji, to jednak zjawisko to pełni istotną funkcję $\mathrm{w}$ sferze dynamiki populacji państw członkowskich UE"126.

Portugalskie władze zaś wydają się w pełni świadome nie tylko sytuacji demograficznej własnego kraju, ale i potrzeby dwutorowego działania w tym obszarze, uwzględniającego zarówno odpowiednie środki zaradcze ze sfery polityki prorodzinnej, jak i migracyjnej ${ }^{127}$.

Ponadto, co niezwykle istotne, dostrzeżenie w przybywających do Portugalii cudzoziemcach potencjalnych współobywateli pociągnęło za sobą krystalizację polityki integracji imigrantów, która to, jak już zostało wspomniane, od 2007 r. zajmuje drugą pozycję w Indeksie Integracji Imigrantów (MIPEX). Przy czym warto

123 R. Matyja, A. Siewierska-Chmaj, K. Pędziwiatr, op. cit., s. 17.

124 Zob. United Nations, World Population Prospects. The 2017 Revision. Key Findings and Advance Tables, New York 2017, https://esa.un.org/unpd/wpp/Publications/Files/WPP2017_KeyFindings.pdf, pdf s. 11, 19, 32 i 51, [data dostępu: 28.07.2017].

125 Przy czym w latach 2010-2015 współczynnik dzietności teoretycznej (total fertility rate) zarówno Polski $(1,33)$, jak i Portugalii $(1,28)$ utrzymywał się poniżej, wynoszącej w przybliżeniu 2,1 , wartości zapewniającej zastępowalność pokoleń, nie osiągając choćby europejskiej średniej $(1,6)$. Podobnie rzecz się ma z wielkościami prognozowanymi. Według rokowań ONZ w latach 2045-2050 współczynnik dzietności teoretycznej Polski uplasuje się na poziomie 1,56, a Portugalii - 1,54. Natomiast w latach 2095-2100 opisywany miernik ma osiągnąć identyczną wartość 1,76 dla obu krajów. Zob. ibid., pdf, s. 11, 38 i 41.

126 Eurostat regional yearbook, 2016 edition, http://ec.europa.eu/eurostat/documents/3217494/ 7604195/KS-HA-16-001-EN-N.pdf/76c007e9-6c1d-435a-97f8-e5ea700aa149, pdf s. 40, [data dostępu: 28.07.2017].

127 Plano Estratégico para..., pdf, s. 4. 
podkreślić fakt, że pomimo kryzysu ekonomicznego z końca pierwszej dekady XXI w. „(...) Portugalia utrzymała inwestycje w integrację, a nawet pracowała nad zwiększeniem ich zasięgu i efektywności" ${ }^{\prime 28}$. Polska natomiast w ostatniej edycji przywoływanego indeksu z 2015 r. znalazła się na 32 miejscu z 38 $8^{129}$, pozostając za Portugalią daleko w tyle.

Otwartość na cudzoziemców jako potencjalnych sąsiadów i współobywateli $\mathrm{w}$ rozumieniu ułatwiania im procesu włączania się w społeczeństwo przyjmujące przejawia się również bardzo wyraźnie w ramach instytucjonalnych portugalskiej polityki integracyjnej. W tym kontekście nie sposób nie wspomnieć o dwojakiego rodzaju, lokalnych i krajowych, ośrodkach wspierania migrantów ${ }^{130}$.

Główną misją Lokalnych Ośrodków Wspierania Integracji Migrantów (Centros Locais de Apoio à Integração de Migrantes - CLAIM) ${ }^{131}$ jest „[b]udowanie mostów kulturowych i językowych z interesantami (...)"132. Do zadań tych ośrodków których na obszarze Portugalii działa obecnie 60 - należy m.in. przekazywanie ogólnych informacji dotyczących newralgicznych dla imigrantów aspektów życia codziennego jak praca, zdrowie czy edukacja, ale i związanych z takimi kwestiami jak połączenie z rodziną. Nadto pośród lokalnych centr funkcjonują także różnego typu Wyspecjalizowane Biura Wsparcia (Gabinetes de Apoio Especializado - GAEI). Oferują one imigrantom pomoc prawną, psychologiczną czy, w razie sytuacji konfliktowej, występują w roli mediatora ${ }^{133}$.

Z kolei powołanie do życia Krajowych Ośrodków Wspierania Integracji Migrantów (Centros Nacionais de Apoio à Integração de Migrantes - CNAIM) ${ }^{134}$ opierało się na idei „centralizacji obsługi klienta oraz osiągnięcia efektów syner-

${ }_{128}$ Migrant Integration Policy Index 2015, http://www.mipex.eu/portugal, [data dostępu: 25.08.2016].

129 Zob. Migrant Integration Policy Index 2015, http://www.mipex.eu/poland, [data dostępu: 25.08.2016].

${ }^{130}$ W 2016 r. zarówno lokalne, jak i krajowe ośrodki wspierania migrantów weszły w skład, podlegającej Wysokiej Komisji ds. Migracji, Krajowej Sieci Wspierania Integracji Migrantów (Rede Nacional de Apoio à Integração de Migrantes). Zob. Portaria n. ${ }^{\circ}$ 203/2016 de 25 de julho, Presidência do Conselho de Ministros, Diário da República n. ${ }^{\circ}$ 141/2016, Série I de 2016-07-25, https:// dre.pt/home/-/dre/75025066/details/maximized?p_auth=8YFiDwDc, art. 1 i 2, [data dostępu: 25.08.2017].

${ }^{131}$ Ośrodki te są kontynuacją, powstających od 2003 r., Lokalnych Ośrodków Wspierania Integracji Imigrantów (Centros Locais de Apoio à Integração de Imigrantes - CLAII). Jak można zatem zauważyć, jest to kolejny przykład odzwierciedlenia w sferze instytucjonalnej położenia większego nacisku na zagadnienia związane z reemigracją. Co się również tyczy ośrodków krajowych.

${ }^{132}$ Alto Comissariado para as Migrações (ACM), Rede de Centros Locais de Apoio à Integração de Migrantes (CLAIM), http://www.acm.gov.pt/-/rede-claii-centros-locais-de-apoio-a-integracao-de-imigrant-3, [data dostępu: 25.08.2017].

${ }^{133}$ Ibid.

${ }^{134}$ Centra te kontynuują działalność Krajowych Ośrodków Wspierania Integracji Imigrantów (Centros Nacionais de Apoio ao Imigrante - CNAI), z których pierwsze dwa (w Lizbonie i Porto) zostały utworzone w $2004 \mathrm{r}$. 
gii w wyniku umiejscowienia wielu instytucji w jednym miejscu"135. Aktualnie działają trzy takie centra. Po jednym w północnej (Porto), środkowej (Lizbona) i południowej (Faro) części Portugalii. A w ramach tych ośrodków, ściśle ze sobą współpracując, funkcjonują biura m.in.: Urzędu ds. Cudzoziemców i Granic, Warunków Pracy, Ubezpieczeń Społecznych oraz Ministerstwa Edukacji. Ponadto, co trudno przecenić, Krajowe Ośrodki Wspierania Integracji Migrantów korzystają $\mathrm{z}$ usług mediatorów międzykulturowych ${ }^{136}$.

Ostatnią z postulowanych przez Rafała Matyję, Annę Siewierską-Chmaj i Konrada Pędziwiatra nadrzędnych wytycznych polskiej doktryny imigracyjnej jest stwarzanie cudzoziemcom o wysokich kwalifikacjach korzystnych warunków osiedlenia i wsparcia w podjęciu pracy ${ }^{137}$. Z podobnym wyzwaniem zdaje się mierzyć obecnie Portugalia. Świadczyć o tym mogą zawarte w przyjętej przez tamtejszą Radę Ministrów Strategii dla migracji na lata 2015-2020 zapisy, zgodnie z którymi w państwie tym „[d]o tej pory rozpatrywano imigrację zasadniczo z biernego punktu widzenia. Portugalia przyjmowała imigrantów, którzy szukali kraju do życia i pracy, robiąc wszystko co w jej mocy, by ich godnie podjąć i zintegrować. Jednak (...) inwestowanie w politykę migracyjną jest również instrumentem modernizacji oraz konkurencyjności, który wymaga organizacji i aktywności. Kapitał ludzki jest dzisiaj uważany za główny katalizator zmian gospodarczych i wzrostu ekonomicznego" ${ }^{138}$. Ponadto w przywoływanym dokumencie ogłoszono, że Portugalia „(...) potrzebuje szerszej i bardziej nowoczesnej polityki migracyjnej, która skoncentruje się na utrzymaniu dodatniego salda migracyjnego przez zintegrowane zarządzanie emigracją i imigracją oraz promowanie kreatywnych rozwiązań problemów krajowej gospodarki. A może się tak stać tylko wtedy, gdy zostanie opracowana polityka przyciągania migrantów, którzy dzięki własnym talentom i umiejętnościom będą w stanie wnieść wkład w rozwój krajowy i regionalny" 139 .

Najnowszą inicjatywą portugalskich władz w tej sferze jest umożliwienie od 1 stycznia 2018 r. szybkiego uzyskania wizy pobytowej przez pochodzących z różnych krajów przedsiębiorców, którzy zamierzają rozpocząć bądź przenieść do Portugalii prowadzoną przez siebie innowacyjną działalność. Będą oni mogli składać wnioski za pośrednictwem platformy internetowej. Proponowane projekty

135 M. Pawlak, M. Bieniecki (2010), Rozwiazzania instytucjonalne stosowane w obszarze obstugi imigrantów w wybranych krajach Unii Europejskiej, Warszawa: Instytut Spraw Publicznych, http:// www.isp.org.pl/files/21050000320294745001281514274.pdf, pdf. s. 14, [data dostępu: 25.08.2017].

136 Alto Comissariado para as Migrações (ACM), Centro Nacional de Apoio à Integração de Migrantes (CNAIM), http://www.acm.gov.pt/-/cnai-centro-nacional-de-apoio-ao-imigrante, [data dostępu: 25.08.2017].

${ }^{137}$ R. Matyja, A. Siewierska-Chmaj, K. Pędziwiatr, op. cit., s. 17.

138 Plano Estratégico para..., pdf s. 6.

139 Ibid. 
będą opiniowane m.in. z perspektywy stopnia ich innowacyjności, zdolności osób nimi zarządzających i potencjału w zakresie tworzenia miejsc pracy dla wykwalifikowanych pracowników ${ }^{140}$. Zakwalifikowane projekty otrzymają wsparcie ze strony certyfikowanych podmiotów - inkubatorów ${ }^{141}$.

Zważywszy na powyższe należy zauważyć, że w Polsce rozpoczęto - mający na celu sprowadzenie do naszego kraju cudzoziemców chcących tutaj rozwijać swoje start-upy - pilotażowy program Poland Prize. Podmiotem odpowiedzialnym za przeprowadzenie tego programu została Polska Agencja Rozwoju Przedsiębiorczości, której prezes Patrycja Klarecka zaręczyła, że „Poland Prize zapewni kompleksowe wsparcie dla młodych innowatorów z zagranicy: od pomocy w osiedleniu się i rozpoczęciu działalności gospodarczej, po kontakty biznesowe z dużymi firmami i inwestorami" ${ }^{142}$.

Położenie szczególnego nacisku na przyciągnięcie do Portugalii migrantów z pożądanym potencjałem (tak intelektualnym, jak i finansowym), jakie można zauważyć w przywoływanych powyżej zapisach Strategii dla migracji na lata 2015-2020 nie oznacza wcale braku jakichkolwiek działań w tej sferze w latach poprzednich. Można tutaj wspomnieć o dwóch narzędziach: tzw. niestałym rezydencie podatkowym (residente não habitual) i złotej wizie (visto gold).

Pierwsze $\mathrm{z}$ wymienionych narzędzi, wprowadzone dekretem $\mathrm{z}$ mocą ustawy z 2009 r. ${ }^{143}$, wiąże się z ustanowieniem specjalnego, nader korzystnego, trybu podatkowego ${ }^{144}$ skierowanego do osób uzyskujących dochód pasywny, wysoko wykwalifikowanych pracowników oraz emerytów. Aby zostać objętym tą formą opodatkowania, z której można korzystać przez 10 lat, najpierw trzeba stać się portugalskim rezydentem podatkowym (residente fiscal). W tym celu należy przebywać

${ }_{140}$ Público, Startup visa. Governo cria visto para empreendedores, https://www.publico.pt/2017/ $\underline{11 / 06 / \text { economia/noticia/governo-vai-criar-visto-para-empreendedores-que-abram-empresas-inova- }}$ doras-em-portugal-1791508, [data dostępu: 06.11.2017].

${ }^{141}$ Zob. Portaria n. ${ }^{\circ}$ 344/2017, de 13 de novembro, Administração Interna e Economia, Diário da República, $1 .^{\text {a }}$ série - N. ${ }^{\circ} 218$ - 13 de novembro de 2017, https://dre.pt/application/file/a/114183497, [data dostępu: 17.11.2017].

${ }_{142}$ Business Insider Polska, Rusza program Poland Prize dla zagranicznych startupów, 08.02.2018, https://businessinsider.com.pl/wiadomosci/poland-prize-program-dla-startupow-od-fundacjistartup-poland-i-mpit/t5kzx0r, [data dostępu: 20.06.2018].

${ }^{143}$ Zob. Decreto-Lei n. ${ }^{\circ}$ 249/2009 de 23 de Setembro, Ministério das Finanças e da Administração Pública, Diário da República, 1. ${ }^{a}$ série - N. ${ }^{\circ} 185$ - 23 de Setembro de 2009, https://dre.pt/ application/file/a/490358, [data dostępu: 20.06.2018].

${ }^{144}$ Spośród korzyści uzyskania statusu niestałego rezydenta podatkowego można wskazać np. objęcie „20\% podatkiem liniowym w Portugalii dochodów z (...) działalności o wysokiej wartości dodanej, wykonywanej w Portugalii. Dochody takie są potraktowane bardzo korzystnie. Opodatkowanie ich na zasadach ogólnych oznaczałoby zastosowanie progresywnej stawki, sięgającej prawie 50\%”. T. Piejak, Lexplorers, blog GWW, Podatkowe dobrodziejstwa Portugalii, 30.08.2017, http:// lexplorers.pl/podatkowe-dobrodziejstwa-portugalii/, [data dostępu: 20.06.2018]. Dla uściślenia, „[d]ochody o wysokiej wartości dodanej to np. dochody architektów, inżynierów, informatyków, lekarzy, aktorów czy też muzyków”. Ibid. 
na terytorium Portugalii przez co najmniej 183 dni w ciągu roku, bądź 31 grudnia danego roku być właścicielem lub najemcą, spełniającego określone warunki, mieszkania. Po uzyskaniu statusu rezydenta podatkowego konieczne jest złożenie wniosku o przyznanie statusu niestałego rezydenta podatkowego. Nie zostanie on jednak nadany osobie, która już uprzednio - biorąc pod uwagę 5 ostatnich lat - była rezydentem podatkowym $\mathrm{w}$ Portugalii. Warto również zaznaczyć, że możliwość uzyskania statusu niestałego rezydenta podatkowego w Portugalii jest otwarta nie tylko dla cudzoziemców, ale i dla obywateli tego kraju, co może przyczyniać się do podjęcia przez nich decyzji o powrocie $\mathrm{z}$ emigracji ${ }^{145}$.

Złota wiza to zaś, obowiązujące na mocy ustawy z 2012 r. ${ }^{146}$, zezwolenie na pobyt wydawane w szczególnym trybie obcokrajowcom spoza UE. Aby móc się o nie ubiegać, należy przez co najmniej 5 lat prowadzić na terytorium Portugalii precyzyjnie określoną „działalność inwestycyjną”. Działalność, w wyniku której zainwestowano w tym kraju nie mniej niż milion euro lub stworzono przynajmniej 30 miejsc pracy, bądź nabyto nieruchomości warte co najmniej 500 tys. euro ${ }^{147}$. „W 2016 r. przywilej ten poszerzono też o osoby, które nabyły i wyremontowały, za co najmniej 350 tys. Euro, ponad 30-letnią nieruchomość usytuowaną na terenie miejskim" ${ }^{148}$.

Podsumowując, występujące między oboma zestawianymi państwami podobieństwa w obrębie zagadnień migracyjnych wydają się wystarczające, aby Polska mogła czerpać z portugalskich doświadczeń w tej dziedzinie. Szczególnie, jeżeli chodzi o podejmowane przez Portugalię działania nakierowane na integrację imigrantów. I chociaż można za Maciejem Duszczykiem postawić pytanie, czy aby dotychczasowy brak w granicach Portugalii - znanych z Francji czy z Niemiec wydarzeń odzwierciedlających silne napięcia społeczne, związane z realizowaną polityką migracyjną, świadczy o sukcesie działań integracyjnych w tym kraju, czy też raczej decydujące znaczenie ma tutaj wielkość strumieni imigracyjnych oraz relatywnie krótki okres napływu cudzoziemcó $w^{149}$ ? Na odpowiedź przyjdzie nam jeszcze poczekać. Niemniej w dzisiejszym świecie brak zainteresowania wypracowaniem i realizacją polityki integracyjnej zdaje się prostą drogą do wcześniejszych czy późniejszych niepokojów społecznych na tle migracyjnym. Z perspektywy

145 Pinto Leite e Machado Vaz - Sociedade de Revisores Oficiais de Contas, Reg. dos Residentes Não Habituais, http://www.pintoleitemachadovaz.pt/pt/servicos/regime-dos-residentes-nao-habituais, [data dostępu: 20.06.2018].

146 Zob. Lei n. ${ }^{\circ}$ 29/2012 de 9 de Agosto, Assembleia da República, Diário da República, 1.a série - N.o 154 - 9 de Agosto de 2012, http://www.sef.pt/documentos/35/LEI\%2029_2012.pdf, [data dostępu: 20.06.2018].

147 Ibid., art. 3 d).

148 TVN 24 BIS, Złoty interes na „złotych wizach”. Portugalia zarabia na milionerach, 25.01.2018, https://tvn24bis.pl/ze-swiata,75/portugalia-gospodarka-zyskala-ponad-3-mld-euro-na-zlotychwizach,809451.html, [data dostępu: 20.06.2018].

${ }^{149}$ M. Duszczyk, op. cit., s. 19. 
Polski niezwykle interesująca wydaje się również portugalska koncepcja umieszczenia w tych samych ramach instytucjonalnych integracji imigrantów i ponownego włączenia do społeczeństwa reemigrantów.

\section{Bibliografia}

\section{I. Źródła}

\section{A. Konstytucje:}

Constituição Política da República Portuguesa, 22 de Fevereiro de 1933, Diário do Govêrno, I Série - Número 43, https://dre.pt/application/dir/pdf1sdip/1933/02/04301/02270236.pdf, [data dostępu: 15.08.2017].

Konstytucja Republiki Portugalskiej z dnia 2 kwietnia 1976 r. (z późniejszymi zmianami, ostatnie wprowadzone ustawa konstytucyjna nr 1 z 20 września 1997 r.), http://libr.sejm.gov.pl/ tek01/txt/konst/portugalia.html, [data dostępu: 22.07.2017].

\section{B. Ustawy:}

Lei Orgânica n. ${ }^{\circ}$ 2/2006 de 17 de Abril, Altera a Lei n. ${ }^{\circ}$ 37/81 de 3 de Outubro (Lei da Nacionalidade), Assembleia da República, http://www.pgdlisboa.pt/leis/lei_mostra_articulado. php?nid=614\&tabela=lei_velhas\&nversao=5\&so_miolo, [data dostępu: 20.06.2018] .

Lei n. ${ }^{\circ}$ 25/94 de 19 de Agosto, Altera a Lei n. ${ }^{\circ}$ 37/81 de 3 de Outubro (Lei da Nacionalidade), Assembleia da República, http://www.pgdlisboa.pt/leis/lei_mostra_articulado.php?nid= 614\&tabela=lei_velhas\&nversao=2\&so_miolo, [data dostępu: 20.06.2018].

Lei n. ${ }^{\circ}$ 27/2008 de 30 de Junho, Assembleia da República, Diário da República, 1. a série N.o 124 -30 de Junho de 2008, https://dre.pt/application/dir/pdf1s/2008/06/12400/0400304018. pdf\#1, [data dostępu: 20.07.2017].

Lei n. ${ }^{\circ}$ 29/2012 de 9 de Agosto, Assembleia da República, Diário da República, 1. a série N.o 154 - 9 de Agosto de 2012, http://www.sef.pt/documentos/35/LEI\%2029_2012.pdf, [data dostępu: 20.06.2018].

Lei n. ${ }^{\circ}$ 26/2014 de 5 de maio, Assembleia da República, Diário da República, 1. ${ }^{a}$ série - N. ${ }^{\circ} 85$ 5 de maio de 2014, https://dre.pt/application/dir/pdf1sdip/2014/05/08500/0260602637. pdf\#1, [data dostępu: 20.07.2017].

Ustawa $z$ dnia 12 grudnia 2013 r. o cudzoziemcach. Dz. U. 2013, poz. 1650.

Ustawa $z$ dnia 13 czerwca 2003 r. o udzielaniu cudzoziemcom ochrony na terytorium Rzeczypospolitej Polskiej. Dz. U. 2003, nr 128, poz. 1176.

\section{Dekrety z moca ustawy:}

Decreto-Lei n. ${ }^{\circ}$ 249/2009 de 23 de Setembro, Ministério das Finanças e da Administração Pública, Diário da República, 1. a série - N.º 185 - 23 de Setembro de 2009, https://dre.pt/application/file/a/490358, [data dostępu: 20.06.2018].

\section{Rozporzadzenia:}

Portaria n. ${ }^{\circ}$ 203/2016 de 25 de julho, Presidência do Conselho de Ministros, Diário da República n. ${ }^{\circ}$ 141/2016, Série I de 2016-07-25, https://dre.pt/home/-/dre/75025066/details/maximized?p_auth=8YFiDwDc, [data dostępu: 25.08.2017].

Portaria n. ${ }^{\circ}$ 344/2017, de 13 de novembro, Administração Interna e Economia, Diário da

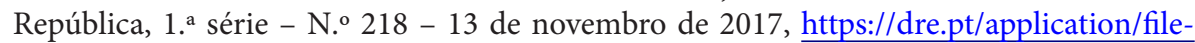
/a/114183497, [data dostępu: 17.11.2017]. 


\section{E. Raporty:}

Abranches M. (2008), INTI Project: One-Stop Shop: A New Answer for Immigrant Integration?, JLS/2006/INTI/148, Country Report for Portugal, http://www.oss.inti.acidi.gov.pt/index. php?option=com_docman\&task=cat_view\&gid=65\&Itemid=57\&lang=en, [data dostępu: 20.04.2011].

Conselho Português para os Refugiados (2014), Relatório de Atividades, http://refugiados.net/1cpr/ www/RelatorioCPR2014.pdf, [data dostępu: 20.07.2014].

Eurostat regional yearbook, 2016 edition, http://ec.europa.eu/eurostat/documents/3217494/ 7604195/KS-HA-16-001-EN-N.pdf/76c007e9-6c1d-435a-97f8-e5ea700aa149, [data dostępu: 28.07.2017].

Relatório de Actividades 2006. Imigração, Fronteiras e Asilo, Serviço de Estrangeiros e Fronteiras (SEF), http://sefstat.sef.pt/Docs/Rifa_2006.pdf, [data dostępu: 08.08.2017].

Relatório de Imigração, Fronteiras e Asilo 2016, Serviço de Estrangeiros e Fronteiras (SEF), https:// sefstat.sef.pt/Docs/Rifa2016.pdf, [data dostępu: 20.06.2018].

United Nations, World Population Prospects. The 2017 Revision. Key Findings and Advance Tables, New York 2017, https://esa.un.org/unpd/wpp/Publications/Files/WPP2017_KeyFindings.pdf, [data dostępu: 28.07.2017].

\section{F. Inne:}

Plano Estratégico para as Migrações (2015-2020), Resolução do Conselho de Ministros n. . 12-B/ 2015, Diário da República, 1. a série - N.o 56 - 20 de março de 2015, http://www.acm.gov. pt/documents/10181/42225/Plano+Estrat\%C3\%A9gico+para+as+Migra\%C3\%A7\%C3\% B5es+\%28PEM\%29_RCM.pdf/b6375f51-53e2-4d88-9783-81cf1c7bb91c, [data dostępu: 19.07.2017].

Polityka migracyjna Polski - stan obecny i postulowane działania. Dokument przyjęty przez Radę Ministrów 31 lipca 2012 r., Warszawa 2012.

Ustawa o zmianie ustawy o udzielaniu cudzoziemcom ochrony na terytorium Rzeczypospolitej Polskiej oraz niektórych innych ustaw, projekt z dnia 30 stycznia 2017 r., https:// bip.mswia.gov.pl/bip/projekty-aktow-prawnyc/2017/24478,Projekt-ustawy-o-zmianie-ustawy-o-udzielaniu-cudzoziemcom-ochrony-na-terytorium-.html, [data dostępu: 21.07.2017].

Ustawa o zmianie ustawy o udzielaniu cudzoziemcom ochrony na terytorium Rzeczypospolitej Polskiej oraz niektórych innych ustaw, projekt z dnia 13 czerwca 2017 r., https://bip. mswia.gov.pl/bip/projekty-aktow-prawnyc/2017/24478,Projekt-ustawy-o-zmianie-ustawyo-udzielaniu-cudzoziemcom-ochrony-na-terytorium-.html, [data dostępu: 21.07.2017].

\section{Opracowania (zwarte, artykuły, inne):}

Alves J.F., Imigração de galegos no Norte de Portugal (1500-1900). Algumas notas, http://ler.letras.up.pt/uploads/ficheiros/artigo11211.pdf, [data dostępu: 21.06.2018].

Baganha M.I. (2003), From Closed to Open Doors: Portuguese Emigration under the Corporatist Regime, „e-JPH”, Vol. 1, number 1, Summer, https://www.brown.edu/Departments/Portuguese_Brazilian_Studies/ejph/html/issue1/pdf/baganha.pdf, [data dostępu: 15.08.2017].

Baganha M.I. (2005) Política de imigração: A regulação dos fluxos, „Revista Crítica de Ciências Sociais”, 73, http://rccs.revues.org/952, pdf s. 4, [data dostępu: 20.08.2017].

Cardoso A.B. (2003), Portugal e a Inglaterra nos Tempos Modernos, „Revista da faculdade de Letras. HISTÓRIA", Porto, III Série, Vol. 4, https://repositorio-aberto.up.pt/bitstream/10216/7966/2/2349.pdf, [data dostępu: 21.06.2018]. 
Cardoso J.L. (2012), Ecos da Grande Depressão em Portugal: relatos, diagnósticos e soluções, „Análise Social”, 203, XLVII (2. $\left.{ }^{\circ}\right), 2012$, https://extranet.uj.edu.pl/ehost/pdfviewer/,DanaInfo=web.ebscohost.com + pdfviewer? vid=4\&sid=eee2b546-dd00-4e1b-b0cb-78bd660e0850\%40sessionmgr111\&hid=125, [data dostępu: 12.05.2013].

Davies N. (2001), Europa: rozprawa historyka $z$ historia, przeł. E. Tabakowska, Kraków: Wydawnictwo ZNAK.

Dionísio E. (2009), Políticas locais e acção colectiva dos imigrantes da Europa de leste, no concetho de Lisboa, Lisboa: Alto-Comissariado para a Imigração e Diálogo Intercultural (ACIDI, I.P.), http://www.oi.acidi.gov.pt/docs/Colec_Teses/tese_27.pdf, [data dostępu: 10.05.2013].

Duszczyk M. (2008), Wyzwania polskiej polityki migracyjnej a doświadczenia międzynarodowe, w: Kaczmarczyk P., Okólski M. (red.) Polityka migracyjna jako instrument promocji zatrudnienia i ograniczenia bezrobocia, Warszawa: Ośrodek Badań nad Migracjami UW.

Gąsior M. (2014), Integracja imigrantów w społeczeństwie osiedlenia na przykładzie Portugalii, praca magisterska napisana w Instytucie Amerykanistyki i Studiów Polonijnych Uniwersytetu Jagiellońskiego.

Higgs D. (1990), Portuguese Migration Before 1880, w: Higgs D. (red.) Portuguese Migration in Global Perspective, Toronto: The Multicultural History Society of Ontario.

Kieniewicz J. (1983), Historia Półwyspu Iberyjskiego, Część I od czasów prehistorycznych do nowożytności, Warszawa: Wydawnictwo Uniwersytetu Warszawskiego.

Klave J.Z. (1985), Historia literatury portugalskiej. Zarys, Wrocław: Zakład Narodowy imienia Ossolińskich Wydawnictwo.

Matyja R., Siewierska-Chmaj A., Pędziwiatr K. (2015), Polska polityka migracyjna. W poszukiwaniu nowego modelu, Warszawa-Rzeszów: Wydawnictwa Uniwersytetu Warszawskiego.

Mc Loughlin S., Münz R. (2011), Temporary and Circular Migration: Opportunities and Challenges, European Policy Centre, Working Paper No. 35, http://www.epc.eu/documents/uploads/pub_1237_temporary_and_circular_migration_wp35.pdf, [data dostępu: 15.07.2017].

Nogueira da Silva C., Grinberg K. (2011), Soil Free from Slaves: Slave Law in Late Eighteenthand Early Nineteenth-Century Portugal, „Slavery \& Abolition”, Vol. 32, No. 3, September, https://extranet.uj.edu.pl/eds/pdfviewer/,DanaInfo=eds.a.ebscohost.com+pdfviewer? vid=2\&sid=f88acd4a-f410-412d-86cb-813d2712977a\%40sessionmgr4006, [data dostępu: 21.06.2018].

Oliveira Marques A.H. de (1987), Historia Portugalii, t. I, przeł. J.Z. Klave, Warszawa: Państwowe Wydawnictwo Naukowe.

Oliveira Marques A.H de (1987), Historia Portugalii, t. II, przeł. W. Chabasiński, Warszawa: Państwowe Wydawnictwo Naukowe, s. 41.

Padilla B., França T. (2016), Migration Policies and Institutional Frameworks. Development and Evolution in Portugal, „Comparative Cultural Studies: European and Latin America Perspectives" 1, http://www.fupress.net/index.php/ccselap/article/view/19987/18624, [data dostępu: 20.07.2014].

Pawlak M., Bieniecki M. (2010), Rozwiązania instytucjonalne stosowane w obszarze obstugi imigrantów w wybranych krajach Unii Europejskiej, Warszawa: Instytut Spraw Publicznych, http://www.isp.org.pl/files/21050000320294745001281514274.pdf, [data dostępu: 25.08.2017].

Peixoto J. (2009), New Migrations in Portugal: Labour Markets, Smuggling and Gender Segmentation, „International Migration” Vol. 47 (3), https://extranet.uj.edu.pl/ehost/pdfviewer/,Da$\underline{\text { naInfo=web.a.ebscohost.com }+ \text { pdfviewer?vid=8\&sid=228649b4-30b3-40ed-b691-ed1898eb }}$ 6a5f\%40sessionmgr4004\&hid=4106, [data dostępu: 15.07.2016]. 
Peixoto J., Sabino C., Abreu A. (2009), Immigration Policies in Portugal: Limits and Compromise in the Quest for Regulation, „European Journal of Migration and Law”, Vol. 11, https:// extranet.uj.edu.pl/ehost/pdfviewer/,DanaInfo=web.ebscohost.com + pdfviewer?vid=5\&h $\underline{\mathrm{id}=107 \& \mathrm{sid}=589 \mathrm{f} 4 \mathrm{c} 4 \mathrm{a}-95 \mathrm{~d} 6-4 \mathrm{a} 0 \mathrm{c}-\mathrm{bf} 9 \mathrm{f}-4 \mathrm{ce} 1 \mathrm{f} 105101 \mathrm{f} \% 40 \text { sessionmgr113, }}$ [data dostępu: 30.05.2013].

Royo S. (2005), Portugal's Migration Experience: Redefined Boundaries and Uneasy Transformations, „Mediterranean Quarterly”, Vol. 16, Issue 4, https://extranet.uj.edu.pl/ehost/pdfviewer/,DanaInfo=web.b.ebscohost.com + pdfviewer? vid=4\&sid=a4d3b0f9-745f-44a8-8be0871386938a6d\%40sessionmgr115\&hid=117, [data dostępu: 20.05.2013].

Saraiva J.H. (2000), Krótka historia Portugalii, przeł. E. Łukaszyk, Kraków: Towarzystwo Autorów i Wydawców Prac Naukowych UNIVERSITAS.

Sousa L., Costa P.M. (2016), A evolução do direito de asilo e regimes de proteção a refugiados em Portugal (1975-2015), Centro de Estudos Judiciários, https://repositorioaberto.uab.pt/bitstream/10400.2/5524/1/costa_sousa_A\%20evolu\%C3\%A7\%C3\%A3o\%20do\%20direito\%20 de\%20asilo\%20e\%20regimes\%20de\%20prote\%C3\%A7\%C3\%A3o\%20a\%20refugiados\%20 em\%20Portugal.pdf, [data dostępu: 21.07.2017].

Tazbir J. (2009), Rzeczpospolita wielu narodów, w: Kłoczowski J. (red.), Rzeczpospolita wielokulturowa - dobrodziejstwo czy obciążenie?, Warszawa: Collegium Civitas Press: Polski Komitet do spraw UNESCO.

Walaszek A. (2013), Dwie europejskie peryferie: porównanie migracji portugalskich i polskich od XVI wieku do Wielkiej Wojny, „Studia Migracyjne - Przegląd Polonijny”, z. 2 (148).

Wituch T. (2000), Historia Portugalii w XX wieku, Warszawa: Wyższa Szkoła Humanistyczna w Pułtusku.

Yeleyko I., Specyfika migracji zarobkowej ludności na Ukrainie, http://ur.edu.pl/pliki/Zeszyt11/30. pdf, [data dostępu: 20.08.2017].

Zagórski B.R. (2009), Orientalizm lub orientalność polskiej wspólnoty etnicznej i politycznej $w$ aspekcie europejskim, w: Kłoczowski J. (red.) Rzeczpospolita wielokulturowa - dobrodziejstwo czy obciążenie?, Warszawa: Collegium Civitas Press: Polski Komitet do spraw UNESCO.

\section{Strony internetowe:}

Alto Comissariado para as Migrações, http://www.acm.gov.pt, [data dostępu: 21.07.2017].

Business Insider Polska, https://businessinsider.com.pl, [data dostępu: 20.06.2018].

Helsińska Fundacja Praw Człowieka, http://www.hfhr.pl, [data dostępu: 21.07.2017].

Instituto Nacional de Estatística, https://www.ine.pt, [data dostępu: 08.08.2017].

Lexplorers, blog GWW, http://lexplorers.pl, [data dostępu: 20.06.2018].

Migrant Integration Policy Index, http://www.mipex.eu, [data dostępu: 25.08.2016].

Ministerstwo Spraw Wewnętrznych i Administracji, https://bip.mswia.gov.pl, [data dostępu: 21.07.2017].

País ao Minuto, https://www.noticiasaominuto.com, [data dostępu: 19.07.2017].

Pinto Leite e Machado Vaz - Sociedade de Revisores Oficiais de Contas, http://www.pintoleitemachadovaz.pt, [data dostępu: 20.06.2018].

Portal das Comunidades Portuguesas, https://www.portaldascomunidades.mne.pt, [data dostępu: 19.07.2017].

Programa Mentores para Migrantes, https://mentores.acm.gov.pt/home, [data dostępu: 22.07. 2017]. 
Público, https://www.publico.pt, [data dostępu: 06.11.2017].

Rede Comum de Conhecimento, http://www.rcc.gov.pt, [data dostępu: 22.07.2017].

República Portuguesa, XXI Governo Constitucional, http://www.portugal.gov.pt, [data dostępu: 19.07.2017].

TVN 24 BIS, https://tvn24bis.pl, [data dostępu: 20.06.2018].

Urząd do Spraw Cudzoziemców, https://udsc.gov.pl, [data dostępu: 20.06.2018]. 